\title{
САМОПОВРЕЖДАЮЩЕЕ ПОВЕДЕНИЕ ПОДРОСТКОВ: ДЕФИНИЦИИ, ЭПИДЕМИОАОГИЯ, ФАКТОРЫ РИСКА И ЗАЩИТНЫЕ ФАКТОРЫ. Сообщение I
}

\author{
Е.Б. Аюбов, П.Б. Зотов, Г.С. Банников
}

Московский НИИ психиатрии - филиал ФГБУ «Национальный медицинский исследовательский центр психиатрии и наркологии им. В.П. Сербского" Минздрава России, г. Москва, Россия ФГБОУ ВО «Тюменский государственный медицинский университет» Минздрава России, г. Тюмень, Россия ФГБОУ ВО “Московский государственный психолого-педагогический университет», г. Москва, Россия

\section{SELF-HARMING BEHAVIOR OF ADOLESCENTS: DEFINITIONS, EPIDEMIOLOGY, RISK FACTORS AND PROTECTIVE FACTORS. The Message I}

\author{
E.B. Lyubov, \\ P.B. Zotov, \\ G.S. Bannikov
}

\author{
Moscow Institute of Psychiatry - branch of National medical research centre \\ of psychiatry and narcology by name V.P.Serbsky, Moskow, Russia \\ Tyumen State Medical University, Tyumen, Russia \\ Moscow State University of Psychology and Education, Moscow, Russia
}

Информация об авторах:

Аюбов Евгений Борисович - доктор медицинских наук, профеcсор (SPIN-код: 6629-7156; Researcher ID: B5674-2013; ORCID iD: 0000-0002-7032-8517). Место работы и домжность: главный научный сотрудник отдемения кАинической и профимактической суицидомогии Московского научно-исследовательского института психиатрии филиала ФГБУ “Национальный медицинский исследовательский центр психиатрии и наркологии им. В.П. Сербского" Минздрава России. Адрес: Россия, 107076, г. Москва, уц. Потешная, д. 3, корп. 10. Телефон: +7 (495) 96375-72, эмектронный адрес: lyubov.evgeny@mail.ru

Зотов Павем Борисович - доктор медицинских наук, професcop (SPIN-код: 5702-4899; Researcher ID: U-28072017; ORCID iD: 0000-0002-1826-486X). Место работы и домжность: заведующий кафедрой онкологии ФГБОУ ВО "Тюменский государственный медицинский университет" Минздрава России. Адрес: Россия, 625023, г. Тюмень, ум. Одесская, д. 54; специалист центра суицидальной превенции ГБУЗ ТО «Областная клиническая психиатрическая больница". Адрес: Тюменская область, Тюменский район, р.п. Винзили, ул. Сосновая, д. 19. Телефон: +7 (3452) 270-510, эмектронный адрес (корпоративный): note72@yandex.ru

Банников Геннадий Сергеевич - кандидат медицинских наук (SPIN-код: 2063-4444; Researcher ID: I-40032013; ORCID iD: 0000-0003-4929-2908). Место работы: старший научный сотрудник отделения клинической и профилактической суицидомогии Московского НИИ психиатрии - ф-м ФГБУ "Национальный медицинский исследовательский центр психиатрии и наркологии им. В.П. Сербского" МЗ РФ. Адрес: Россия, 107076 Москва, ул. Потешная, д. 3; заведующий мабораторией научно-методического обеспечения экстренной психологической помощи Центра экстренной психологической помощи ФГБОУ ВО “Московский государственный психолого-педагогический университет". Адрес: 127051, Москва, ул. Сретенка, д. 29. Темефон: (495) 963-75-72, электронный адрес: bannikov68@mail.ru

Contact Information:

Lyubov Evgeny Borisovich - Ph.D., Professor (SPIN-code: 6629-7156; Researcher ID: B-5674-2013; ORCID iD: 00000002-7032-8517). Place of work: Chief Researcher, Clinical and Preventive Suicidology Division, Moscow Research Institute of Psychiatry, a branch of the National Medical Research Center for Psychiatry and Narcology named after V.P. Serbsky. Address: Russia, 107076, Moscow, 3/10 Poteshnaya str. Phone: +7(495) 963-75-72, email: lyubov.evgeny@mail.ru

Zotov Pavel Borisovich - Ph.D., Professor (SPIN-code: 5702-4899; Researcher ID: U-2807-2017; ORCID iD: 00000002-1826-486X). Place of work: Head of the Department of Oncology, Tyumen State Medical University. Address: Russia, 625023, Tyumen, 54 Odesskaya str; Specialist of the Center for Suicidal Prevention of Regional Clinical Psychiatric Hospital. Address: Tyumen region, Vinzili, 19 Sosnovaya str. Phone: +7 (3452) 270-510, email (corporate): note72@yandex.ru

Bannikov Gennady Sergeevich - M.D. (SPIN- code: 2063-4444; Researcher ID: I-4003-2013; ORCID iD: 0000-00034929-2908). Place of work: Older Researcher, Clinical and Preventive Suicidology Division, Moscow Research Institute of Psychiatry, a branch of the National Medical Research Center for Psychiatry and Narcology named after V.P. Serbsky. Address: Russia, 107076, Moscow, 3/10 Poteshnaya str.; head of laboratory, Center of Emergency Psychological Aid, Moscow State University of Psychology \& Education. Address: 127051, Moscow, 29 Sretenka st. Email: bannikov68@mail.ru

В серии обзоров систематизированы и критически осмыслены результаты отечественных, включая оригинальные, и зарубежных исследований с опорой на доказательные данные о суицидальном поведении. В настоящем Сообщении I даются чёткие характеристики отдельных форм суицидального поведения и несуицидального самоповреждения, их различия, эпидемиологические показатели в подростковом периоде и в сравнении со взрослой популяцией. Подробно рассматриваются факторы риска и антисуицидальной защиты, способы суицидальных действий. Обсуждается роль в суицидальной активности лиц данной возрастной категории таких показателей как пол, возраст, раса и этническая принадлежность и др. При оценке суицидального риска показана важная роль суицидального анамнеза (покушения на суицид в прошлом) и наличие несуицидальных самоповреждений, рискованного поведения. Приводятся данные об аффективных, когнитивных и социальных факторах риска суицидального поведения, личностных и психологических особенностях. В частности, показана роль в суицидогенезе агрессии и импульсивности, нейротизма, негативной аффективности, низкой само- 
оценки, недостаточной стрессоустойчивости, сексуальной ориентации, употребления ПАВ и др. В заключении авторы делают вывод о многофакторности развития суицидального поведения в подростковом возрасте и необходимости дальнейших исследований.

Ключевые слова: аутоагрессия, суицид, суицидальная попытка, подростки, модели суицидогенеза, факторы риска, профилактика суицида

Каждый третий землянин - ребёнок (по конвенции $\mathrm{OOH,} \mathrm{каждый} \mathrm{человек} \mathrm{младше} 18$ лет). Подростковый возраст - важнейший в развитии. Бурные стрессогенные биологические и психосоциальные изменения второго десятилетия отражаются на всех аспектах жизни подростков; уникальный период цикла развития важен для гармонизации душевного и физического благополучия в дальнейшем.

Суицидальное поведение (СП) детей и подростков как неизменно актуальная проблема общественного здравоохранения вызывает особую озабоченность по ряду причин.

Треть из 800000 гибнущих ежегодно от самоубийств в мире - молодые. Самоубийство одна из ведущих причин смертности в мире во всех возрастах [1]: 1,5\% всех смертей в мире, или 18 место в ранжире причин смерти, но вторая по частоте причина смертей детей и подростков Европы и США вслед дорожно - транспортным несчастным случаям [1]. На самоубийства приходятся 8,5\% смертей подростков и молодых 15-29 лет, они же основная причина их смерти в мире $[2,3]$.

В подростковом возрасте - начало большинства потенциально суицидогенных психических (как депрессия) и ряда соматических (как аутоиммунные) расстройств.

В связи с ростом СП с возрастом, подростки главная мишень профилактики. Основная цель профилактики СП подростков - уменьшение факторов риска и противодействие им.

СП подростков связано с физическими и неврологическими последствиями и инвалидностью; влечёт тяжелое социально-экономическое и психологическое бремя [1], поэтому у программ профилактики гуманный и ресурсосберегающий потенциал.

Подростки с СП и их близкие склонны уклоняться от типовой профессиональной помощи, мало соответствующей возраст - специфическим и эластичным по мере развития их потребностям, что побуждает развитие новых форм в русле матрицы общественного здравоохранения, ориентированного на личностно - социальное развитие (восстановление).

Научно доказательно эффективные лечение и профилактика СП подростков гуманны и несут ресурсосберегающий потенциал. Вместе с тем недостаточно изучены многообразные факторы риска СП в динамическом взаимодействии с защитными факторами, суицидогенез, недостаточно разработаны новые и оценены существующие организационно-функциональные фор-
Every third inhabitant of the earth is a child (according to the UN convention, a child is any person under 18 years of age). Adolescence is the most important age in humna development. Violent stressful biological and psycho-social changes in the second decade are reflected in all aspects of adolescent life; a unique period of the development cycle is important for the harmonization of mental and physical well-being in the future.

Suicidal behavior (SB) of children and adolescents as a constantly topical public health problem is of particular concern for a number of reasons.

A third of the 800,000 deaths per year from suicides in the world is by young people. Suicide is one of the leading causes of death in the world at all ages [1]: $1.5 \%$ of all deaths in the world, or 18th place in the ranking of causes of death, but the second most common cause of death of children and adolescents in Europe and the United States following road traffic accidents [1]. $8.5 \%$ of the deaths of adolescents and young people aged 15-29 are suicidal, and this is the main cause of youth death in the world $[2,3]$.

The onset of most potentially suicidogenic mental (like depression) and a number of somatic (like autoimmune) disorders happens in adolescence.

Since SB is growing with age, adolescents are the main target of prevention. The main goal of prevention of suicide behavior in adolescents is to reduce risk factors and counteract them.

SB of adolescents is associated with physical and neurological consequences and disability; entails a heavy socio-economic and psychological burden [1], therefore, prevention programs have a humane and resourcesaving potential.

Adolescents with SB and their relatives tend to evade from standard professional help because it doesn't usually address age specific demands including its elasticity and need to evolve. As a result, new forms in line with the matrix of public health focused on personal and social development (recovery) are encouraged to develop.

Scientifically effective treatment and prevention of SBs of adolescents are humane and bear resource-saving potential. At the same time, the diverse risk factors of SP in dynamic interaction with protective factors, suicidogenesis are not sufficiently studied, new organizational and functional forms of 
мы помощи в разнородной группе подростков - суицидентов и их близких с учётом возрастного этапа развития и хронотопа (школа, дом, интернат, больница, пенитенциарное учреждение).

Организация и апробация результативности, с привлечением позиции суицидентов и их близких, подросткового сектора суицидологической помощи вписаны в русло «Стратегии развития системы охраны психического здоровья в Российской Федерации до 2025 г.», предусматривающей обеспечение необходимых условий для разработки инновационных, ресурсосберегающих программ психопрофилактики, психообразования и психопросвещения, адресованных потребителям психиатрической помощи и населению в целом на разных этапах жизненного цикла человека.

Определения и феноменология СП.

Подростковый возраст - переходный период развития человека между детством и зрелостью. Согласно терминологии Фонда ООН в области народонаселения, подростки - лица 10-19 лет (ранний подростковый возраст 10-14 лет; поздний подростковый возраст 15-19 лет).

В литературе широко определение СП вне последовательных систематики и рабочих определений. Каждые несколько лет обновлена таксономия СП. В исследованиях СП возможны феноменологические различия: активные или пассивные мысли; попытка самоубийства с медицинскими последствиями или без них. При неясности таксономии и набора операциональных определений без детализации этапа суицидогенеза в выборках страдает внутренняя валидность исследований (как «случай-контроль») с «диффузией» групп изучения и контроля. Важно детализировать и стандартизировать определение СП.

Суицидальные мысли в настоящем обзоре - размышления или желание покончить с собой от относительно пассивных (желание умереть) до активных (желание убить себя или планирования, как это сделать), о причинении себе вреда или самоубийстве. Обычно в исследованиях «серьёзные» мысли о суициде не отличают от антивитальных переживаний.

В обзоре прицельно не обсуждены планы самоубийств из-за отсутствия консенсусного определения и задокументированного отличия несоответствия лиц, сообщающих о запланированных и незапланированных попытках.

СП определено как умышленное или совершаемое неосознанно физическое самоповреждение, чреватое медицинскими последствиями и смертью.

Суицидальное поведение [4] объединяет проявления суицидальной внутренней и внешней активности: мысли, намерения, высказывания, угрозы, попытки, суицид. Термин особо применим к подростковому возрасту, когда суицидальные проявления многообразны. care in a heterogeneous group of adolescents suicides and their relatives are insufficiently developed and evaluated, taking into account the age stage of development and chronotope (school, home, boarding school, hospital, penitentiary institution).

The organization and testing of effectiveness, involving the position of suicides and their relatives, the teenage suicidological care sector are included in the mainstream of "Strategies for the development of the mental health system in the Russian Federation until 2025", which provides for the provision of the necessary conditions for the development of innovative, resource-saving general programs of psychoprophylaxis, psychoeducation and psychoeducation, addressed to consumers of psychiatric care and to the population as a whole at different stages of a person's life cycle.

Definitions and phenomenology of the SB.

Adolescence is a transitional period of human development between childhood and adulthood. According to the terminology of the United Nations Population Fund, adolescents are people of 10-19 years of age (early adolescence is the period between 10 and 14 and late adolescence is between 15 and 19).

In the literature, the definition of a SB is too broad and has few consistent systematics and working definitions. Every few years, SB taxonomy is updated. In SB research, phenomenological differences are possible: active or passive thoughts; suicide attempt with or without medical consequences. If the taxonomy and the set of operational definitions are unclear without specifying the stage of suicide genesis in the samples, the internal validity of the studies suffers (as in "case-control") because there will be "diffusion" of the study and control groups. It is important to detail and standardize the definition of SB.

The suicidal thoughts, or suicide ideation, in this review means thoughts or the desire about harming oneself or committing suicide that can take either relatively passive (the desire to die) to rather active forms (the desire to kill oneself or planning how to do this). Usually in studies, "serious" thoughts of suicide do not distinguish from anti-vital experiences.

The review did not specifically address suicide plans due to the lack of a consensus definition and the documented difference in the mismatch of individuals reporting planned and unplanned attempts.

SB is defined as intentional or unconsciously committed physical self-harm that can lead to medical consequences and death.

Suicidal behavior [4] combines the manifestations of suicidal internal and external activity: thoughts, intentions, statements, threats, attempts, suicide. The term is especial- 
Континуум от суицидальной мысли до суицида [1], представляют полюса спектра риска СП.

Попытка самоубийства - несмертельное, саморазрушительное действие с явным или предполагаемым намерением умереть. Попытка самоубийства подростков чаще (60-80\%) запланирована [5]. В противовес отечественным данным. Лишь у $10 \%$ подростков истинное желание покончить с собой, у остальных «крик о помощи». У подростков различие меж истинными и демонстративными суицидальными попытками затруднено. При «неясных» попытках действия определены бурным аффектом при угнетении рассудочной деятельности. Малоопасный или брутальный способы могут быть выбраны случайно [6].

Самоубийство - самоповреждающий смертельный поступок с явным или предполагаемым намерением лишить себя жизни, что часто определено судмедэкспертом или доверенным лицом.

В обзоре рассмотрены и несуицидальные самоповреждения (НС), суицидальный жест, парасуицид), то есть самоповреждения без суицидального намерения. Шире: парасуициды - суицидальные попытки $u$ намеренные самоповреждения без намерения умереть [7].

Несуичидальное самоповреждение есть действие с несмертельным летальным исходом, при котором лицо преднамеренно демонстрирует непривычное для себя поведение, приводящее, при отсутствии вмешательства со стороны, к самоповреждению, либо преднамеренно принимает какое-либо вещество в дозе, превышающей предписанную, целью чего служит осуществление желаемых данным лицом перемен посредством фактических или ожидаемых физических последствий.

Термин «преднамеренное самоповреждение» применим и для самоповреждений, не предполагающих суицидальных намерений с целью «побега», а не смерти.

У подростков сочетается несуицидальное и СП, феноменологически разные. Граница между суицидальными и несуицидальными намеренными самоповреждениями размыта, происходит «перехлёст», и квалифицировать попытку, особо ретроспективно и у подростков, нелегко.

Защитный фактор обозначает фактор, уменьшаюший групповой и индивидуальный риски СП.

Эпидемиология СП подростков.

Суицидальные мысли редки до 10 лет с пиком в 1217 лет [5]. Суицидальные мысли типичны особенно у девочек.

Многие суициденты помышляли о суициде или пытались покончить с собой ещё подростками, что указывает важность ранней профилактики СП. Самоотчёты и мониторинг в режиме реального времени свидетельствуют, что подростки если уж размышляют о суициде, то умеренно часто, например, «один раз в неде- ly applicable to adolescence when suicidal manifestations are diverse. The continuum from suicidal thought to suicide [1] represents the poles of the risk spectrum of SB.

A suicide attempt is a non-lethal selfdestructive act with an explicit or alleged intention to die. Attempted suicide of adolescents is more often $(60-80 \%)$ planned [5] in contrast to domestic data. Only $10 \%$ of adolescents have a true desire to commit suicide, while the rest use it as a "cry for help". In adolescents, the distinction between true and demonstrative suicidal attempts is difficult. With "unclear" attempts, actions are determined by tempestuous affect with the rational activity suppressed. Low-risk or brutal methods can be chosen randomly [6].

Suicide is a self-harming death act with an explicit or implied intent to take life, which is often determined by a medical examiner or a trustee.

The review also considers non-suicidal self-harm (NSSH, suicidal gesture, parasuicide), that is, self-harm without suicidal intent. To take it wider: parasuicides are suicidal attempts and intentional self-harm without the intention of dying [7].

Non-suicidal self-harm is an action with a non-fatal outcome when a person either intentionally demonstrates some non-typical behavior that can lead to self-harm in the absence of outside interference, or intentionally takes some substances exceeding the prescribed dose, with the purpose of initiating some desired by that person changes through actual or expected physical consequences.

The term intentional self-harm is also applicable to self-harm that does not involve suicidal intentions with the "escape" rather than death motive.

In adolescents, non-suicidal and SB are intertwined even though they are phenomenologically different. The border between suicidal and non-suicidal intentional self-harm is blurred, with an "overlap" occurring, and it is not easy to identify an attempt, especially retrospectively in adolescents.

A protective factor refers to a factor that reduces the group and individual risks of SB.

Epidemiology of adolescents SB.

Suicidal thoughts are rare up before 10 years of age with a peak at 12-17 [5]. Suicidal thoughts are more typical of girls.

Many suicide attempters thought of suicide or tried to commit suicide as teenagers, which indicates the importance of early prevention of SB. Self-reports and real-time monitoring indicate that if adolescents think about suicide, they tend to do it moderately often, for example, "once a week".

So, every fifth or fourth teenager in different countries thinks about suicide [5, 8]. 
лю». Так, каждый пятый-четвертый подросток разных стран думает о суициде $[5,8]$. Частота вновь выявленных суицидальных мыслей подростков 15-25\%, по тяжести от мыслей о смерти и пассивных мыслей до конкретных суицидальных мыслей с намерением или планом.

Частота мыслей подростков о самоубийствах слабо коррелируют с национальными уровнями суицидов (УС) при отсутствии надёжных данных регистрации актов гражданского состояния в большинстве стран и занижении или неверной классификации самоубийств, особо подростков.

Планирование реже: 6 и 2\% новых случаев в год у девочек и мальчиков-подростков соответственно [9]. В семьях с малыми доходами подростки 16-18 лет проявляют суицидальную активность в 1,5 раза чаще [10].

Частые, серьёзные и хронические (неотступные) раздумья о суициде связаны с его попыткой [11] в течение 1-2 лет [12] и клинически представлены обычно депрессией / дистимией [5]. Думающие о суициде подростки в 12 раз вероятнее совершат попытку к 30 годам [13], более трети - суицид [5].

Дезадаптивными формами «отвлечения» от тягостных мыслей служат НС и /или употребление ПАВ.

В большинстве стран суицидальное мышление обусловлено травлей и физическим насилием, одиночеством, недостаточной поддержкой родителей, употреблением спиртного и табакокурением [14], то есть сходными фасадными причинами, как и внешних форм СП.

Суицидальные попытки - начало несколько позже мыслей; редки до 12 лет, учащаясь в подростковом возрасте [5, 12], выходят на плато после 20 лет.

Распространённость попыток самоубийств в течение жизни $3-10,5 \%[5,15]$; у $1,3-3,8 \%$ мальчиков и $1,5-10 \%$ девочек, чаще - у девушек-старших подростков [9]. Попытки с медицинскими последствиями, возможно, составляют не более 1-3\% от всех, но реальное их число занижено, поскольку большинство не обращается за медицинской помощью, попытки неточно задокументированы [9].

В клинических выборках суицидальные попытки старших подростков обычно повторные с удлинением интервала. Повторное СП (более продуманное и брутальное) может быть предвестником самоубийства.

Несуичидальные самоповреждения (НС), часто повторные, характерны для подростков $[16,17]$ с пиком в 12-14 лет [18]. Так, 7,5-46,5\% (в среднем каждый пятый) подростков в мире совершают $\mathrm{HC}$ против 4-23\% взрослых. Частота НС европейских подростков не менее 10-13\%; девушки втрое чаще сообщают о НС. В ряде стран НС - ведущие причины госпитализаций подростков в многопрофильные больницы, но малая доля прибегающих к $\mathrm{HC}$ подростков обращается за
The frequency of newly identified suicidal thoughts of adolescents is $15-25 \%$, and they range in severity from thoughts of death and passive thoughts to detailed suicidal thoughts with an intention or plan.

The frequency of teenagers' thoughts on suicides is weakly correlated with national suicide rates in the absence of reliable data on registration of acts of civil status in most countries and an underestimation or incorrect classification of suicides, especially for adolescents.

Frequency of planning is gender- and socially related: there are reported to be 6 and $2 \%$ of new cases per year for adolescent girls and boys respectively [9]. In families with low incomes, adolescents 16-18 years old show suicidal activity 1.5 times more often [10].

Frequent, serious and chronic (persistent) thoughts about suicide are associated with a suicide attempt in the last 1-2 years $[11,12]$ and are usually clinically represented by depression / dysthymia [5]. Teenagers who think about suicide are 12 times more likely to attempt suicide by the age of 30 [13] and more than one third of them would commit actual suicide by that time [5].

Disadaptive forms of "distraction" from painful thoughts are NSSH and / or substance abuse.

In most countries, suicidal ideation is caused by bullying and physical abuse, loneliness, insufficient parental support, alcohol and tobacco smoking [14], that is similar facade reasons that are observed for external forms of SB.

Suicidal attempts usually begin a little later after thoughts start; they are rare before the age of 12 , become more frequent in adolescence $[5,12]$, and reach a plateau after 20 years of age.

The prevalence of suicide attempts in life is $3-10.5 \%[5,15]$; it is $1.3-3.8 \%$ for boys and $1.5-10 \%$ for girls, more typical for lateadolescent girls [9].

Attempts with medical consequences probably make up no more than $1-3 \%$ of all attempts, but their real number is underestimated, since most attempters do not seek medical help and attempts themselves are not accurately documented [9].

In clinical samples, suicidal attempts by older adolescents are usually repeated with an extended interval. Repeated SB (more planned and brutish) can be a predictor of suicide.

Non-suicidal self-harm (NSSH), often repeated, is characteristic of adolescents [16, 17] and peaks at 12-14 [18]. Thus, $7.5-46.5 \%$ (on average one in five) of adolescents in the world commit NSSH while 4-23\% adults do it. The incidence of NSSH in European adolescents is at least $10-13 \%$; girls are three times more likely to report NSSH. In a number of 
психологической и психиатрической помощью [16].

Распространённость и клиническая важность позволили рассматривать НС диагностической категорией DSM-V.

Факторы риска НС подростков схематично разделены на внешние (средовые или психосоциальные факторы и травматические события) и внутренние (личностные) [19]. Причины НС объяснены дисрегуляцией эмоций и привлечением внимания. Корреляты НС включают историю сексуального насилия, алекситимии, враждебности [20], сходно с СП. При этом НС и суицидальные самоповреждения сосуществуют. Наиболее важные факторы риска НС и суицидальных попыток подростков: возраст и женский пол, а также незанятость, изменения жизненной ситуации, психическое расстройство (как депрессия, пограничное личностное расстройство) и предыдущие парасуициды [7].

В отечественной выборке 150 столичных учащихся около 14 лет, совершивших НС, 3/4 девушек [21]. Наиболее часты самопорезы (65\%). Выделены аффективные и импульсивные НС для облегчения невыносимого напряжения, с последующим раскаянием; продуманные с подавленностью, гневом с мотивом протеста. Возможна смерть из-за недооценки последствий избранного способа. НС на фоне сниженного настроения у $45 \%$ для облегчения психических переживаний. Как правило, подростки ищут помощи, сочувствия. На фоне заниженной самооценки, неуверенности совершают СП с целью доказать себе и окружающим состоятельность. СП часто носит обсессивно - компульсивный характер. Отношение к СП двойственное в зависимости от позиции окружающих, разочарование сменяется чувством гордости за себя. Психопатоподобный механизм связан с акцентуациями личности пограничного и нарциссического типов в состоянии аффективно суженного сознания, ненависти к себе и окружающим. Мотив «возвращения в реальность», мести. Демонстративношантажное СП позволяет показать исключительность, манипулировать окружающими.

Cyuщиды, редки у детей, но описаны с 5-8 лет [22, 23] и чаще к 15-19 годам. Наибольший скачок УС меж ранним подростковым и молодым возрастами [3], вырастая на два порядка. УС обычно выше у юношей в отличие от суицидальных попыток («гендерный парадокс»). Всемирная Психиатрическая Ассоциация среди уязвимых к самоубийствам возрастных групп выделяет старших подростков 15-19 лет [24].

Усредненные УС в мире 10,$5 ; 13,7$ и 7,5 (здесь и далее на 100000 сверстников) у юношей и девушек соответственно [3].

УС особо высоки в постсоветских странах (Латвии, Узбекистане) 14,5-24 у подростков и молодых и 0,3-2,8 - детей и подростков [25]. УС подростков 10-14 лет 1,6, в 15-19 лет - 8,4. Следственный комитет РФ указы- countries, NSSH is the leading causes of admission of adolescents to multidisciplinary hospitals, but a small proportion of adolescents that practice NSSH seek psychological and psychiatric help [16].

The prevalence and clinical importance made it possible to consider NSSH as a diagnostic category of DSM-V.

Risk factors for adolescent NSSH are schematically divided into external (environmental or psychosocial factors and traumatic events) and internal (personality related) [19]. The causes of NSSH are explained by dysregulation of emotions and attracting attention. Correlates of NSSH include a history of sexual violence, alexithymia, hostility [20], which is similar to the SB. In this case, NSSH and suicidal self-harm coexist. The most important risk factors for NSSH and suicide attempts for adolescents are age and female gender, as well as inoccupation, changes in life situation, mental disorder (such as depression, borderline personality disorder) and previous parasuicides [7].

In the domestic sample of 150 students of capital schools aged 14 who committed NSSH, $3 / 4$ are females [21]. Self-cuts are most common (65\%). Affective and impulsive NSSH types are highlighted that are used to alleviate unbearable stress (often followed by remorse) and carefully thought over with low-spiritedness and anger with a motive of protest. Death becomes possible due to underestimation of the consequences of the chosen method. NSSH can take place on the basis of decreased mood in $45 \%$ to facilitate mental experiences. As a rule, teenagers are looking for help and sympathy. Because of low self-esteem or feeling insecure, they can attempt suicide in order to prove themselves and others their worthiness. SB is often obsessivecompulsive in nature. Attitude to SB is dual and depends on the position of those around the teenager, disappointment is transformed into self-pride. The psychopathic mechanism is associated with personality accentuations of borderline and narcissistic types in a state of narrowed consciousness, hatred of self and others. This can take on motive of "returning to reality" or revenge. Demonstrative intimidate SB allows them to show their exclusivity and to manipulate others.

Suicides are rare for children but are reported from 5-8 years of age [22, 23] and happen more often around the age 15-19. The greatest leap in suicide rates is observed between early adolescence and youth [3], with a two-fold increase. Suicide rate is usually higher for young men, in contrast to suicidal attempts ("gender paradox"). The World Psychiatric Association identifies older adolescents aged 15-19 as a vulnerable suicidal age group [24].

The average suicide rates in the world are 
вает вдвое больше несовершеннолетних жертв суицида. УС селян $(2,3)$ выше втрое такового у горожан, в общем населении - вдвое. Половое соотношение жертв суицида (юноши / девушки) 3:1 при бо̀льшем УС юношей почти вдвое; соотношение УС подростков мужского и женского полов в разных странах 2-8:1 [26]. УС в Федеральных округах (ФО) различны до порядка. Регионы с наибольшими УС подростков отличаются и максимальной частотой УС общего населения. УС подростков - отражение УС взрослых на региональном и государственном уровнях $[27,28,29]$

В группу стран с высокими УС молодежи входят Финляндия и Япония. Тенденции УС подростков не обязательно зеркальное отражение национального УС. Так, Узбекистан входит во вторую сотню рейтинга ВОЗ по УС; Новая Зеландия занимает высокое место по сравнению с другими странами по УС молодежи (529 лет) при относительно низком УС в целом. У Венгрии традиционно лидирующее место в мире по общему УС при относительно низком - молодёжи. В Литве и Латвии высоки УС молодёжи и в общем населении.

Большинство исследований СП подростков из Северной Америки и Западной Европы, но наибольшие УС в «незападных» странах [3].

Самоубийства - актуальная проблема «богатых» стран (с высоким уровнем дохода), но $80 \%$ суицидов в странах с низким и средним уровнями, несущих большую часть общемирового бремени самоубийств. В странах с низким и средним доходами живут более $90 \%$ подростков мира, определяющих $75 \%$ смертей от суицидов [1]. УС обоих полов минимальны до 15 лет. В некоторых регионах мира УС неуклонно растёт с возрастом, но в других пик УС молодежи. В странах с низким и средним уровнем дохода у молодых выше УС, чем у сверстников в странах с высоким уровнем дохода [1]. При этом частота суицидов подростков недооценена минимум на треть (по Дюркгейму, искажение статистики начинается с семьи); но и у взрослых до $100 \%$ и более [30].

Долговременная тендениия. В течение последнего десятилетия в ряде стран значительно уменьшение самоубийств подростков при снижении УС общего населения. Возможные объяснения спада в США и Австралии связаны с более строгими законами об оружии. Фармакоэпидемиологические исследования показали зависимость «доза-ответ» увеличения назначений (продаж) СИОЗС и снижения УС юных [31]. Более характерны многократные колебания УС подростков в различные годы. Причины роста УС неясны и не объяснимы лишь лучшей выявляемостью (как перекодировкой непреднамеренной асфиксии подростков, играющих в «удушение») или суицидогенным эффектом антидепрессантов. Возможные объяснения: рост употребления ПАВ, депрессии, семейной и социальной дез-
10.5 (hereinafter per 100,000 persons); with average 13.7 and 7.5 for boys and girls respectively [3].

Suicide rates are especially high in postSoviet countries (Latvia, Uzbekistan) 14.5-24 in adolescents and young people and 0.3-2.8 in children and adolescents [25]. Suicide rate for 10-14 year-old teenagers reaches 1.6 and for 15-19 years-olds - 8.4. The Investigative Committee of the Russian Federation indicates twice as many juvenile victims of suicide. Suicide rates for teenagers living in villages (2.3) is three times higher than for those living in towns, in the general population it is twice as high. The sex ratio of suicide victims (boys / girls) is 3: 1, with suicide rates for boys almost doubled; the ratio of suicide rates for adolescent males and females in different countries is 2-8: 1 [26]. Suicide rates in Federal Districts (FD) are dramatically different. The regions with the highest suicide rates for adolescents also differ in the maximum frequency of suicide rates for the general population. Suicide rates of adolescents can be viewed as a reflection of the suicide rates of adults at the regional and state levels [27, 28, 29].

The group of countries with high youth suicide rates includes Finland and Japan. Trends in suicide rate of youngsters is not necessarily a mirror image of the national suicide rate. For example, Uzbekistan is in the second hundred of the WHO ranking on suicide in general public; New Zealand ranks high in comparison with other countries in terms of youth suicide rates (5-29 years) with a relatively low suicide rate in general. Hungary has traditionally taken the leading place in the world in terms of general suicide rate with a relatively low one for youth. In Lithuania and Latvia, both youth population and general population are high in suicide rates.

The majority of studies of SB of adolescents come from North America and Western Europe, but the largest suicide rates are in "non-Western" countries [3].

Suicides are an urgent problem for "rich" (high-income) countries, but $80 \%$ of suicides take place in low- and middle-level countries bearing the bulk of the global suicide burden. More than $90 \%$ of adolescents in the world live in low- and middle-income countries, accounting for $75 \%$ of deaths from suicide [1]. Suicide rate of both sexes is minimal up to 15 years of age. In some regions of the world, the suicide rate is growing steadily with age, but in others, it peaks in adolescence. In low- and middleincome countries, young people have higher suicide rate than their peers in high-income countries [1]. Moreover, suicide rate for adolescents is underestimated by at least a third (according to Durkheim, the distortion of statistics begins with the family); but the picture is simi- 
организации, облегчение доступа к средствам суицида. Способы суицида.

Ведущие способы у подростков представлены самоповешением (тренд роста), самоотравлением (передозировка лекарств, настораживает - психотропных) и огнестрелами [22]. Самоудушение чаще у детей, чем подростков, а ножи (бритвы) чаще выбирают подростки, чем взрослые. Подростки и дети, жертвы самоубийства, по сравнению со взрослыми, реже в опьянении или совершали ранее попытки самоубийств [32]. Суицид прыжком с «мостов самоубийц» редок, но резонансно, благодаря СМИ. В географических регионах различия связаны с доступом к смертельным средствам. Так, смерть в результате прыжка под колеса (поезда) чаще у подростков в регионах с развитой железнодорожной сетью, а больше утоплений в поселениях, видимо, у реки и водопадов.

Показательна и когорта французских подростков до 15 лет после суицидальной попытки (самоотравления у $84 \%$ ), требующей краткосрочной госпитализации в общую больницу. Суициденты большей частью (86\%) девочки менее трети жили в полной семье, у $27 \%$ снижена успеваемость. У половины выявлен «хотя бы один психиатрический симптом» (но половина «психически здорова» при психиатрическом обследовании). В течение года около $15 \%$ госпитализированы в психиатрическую больницу в связи с повторной попыткой, $21 \%$ не получали рекомендованного лечения [33].

Факторы риска и антисуицидальные факторы.

Факторы риска и защиты рассмотрены [34] на:

1) физическом или биосоматическом уровнях, включающих физические обстоятельства, генетику, здоровье и болезни;

2) психическом или психологическом уровнях, означающих психическое здоровье, самооценку и способность справляться с трудными обстоятельствами, управлять эмоциями или дистрессом;

3) культурном уровне, или в более широкой жизненной среде (социальные, политические, экологические и экономические факторы, способствующие доступным вариантам и качеству жизни);

4) социальном уровне: отношения и участие с людьми (семья, друзья, сотрудники, более широкое сообщество и чувство принадлежности к человечеству);

5) духовном уровне (вера, надежда, милосердие, отчаяние, спасение).

При недостатке экспериментальных исследований (не всегда выполнимых по этическим соображениям), демографические, средовые, клинические и биологические факторы нельзя автоматически соотнести с причинными. Взамен указаны корреляты и факторы риска, связанные (синхронизированные) с СП (как мысли) или в последующий момент времени. Они отличаются lar for adults - up to $100 \%$ or even higher [30].

Long term trend. Over the past decade, in a number of countries, there has been a significant reduction in suicides of adolescents with a similar decrease in suicides in general population. Possible explanations for the recession in the United States and Australia can be related to implementing stricter gun laws. Pharmaco-epidemiological studies have shown a dose-response relationship with an increase in prescribing (sales) of SSRIs and a decrease in the young people's suicide rates [31]. Multiple fluctuations in adolescents suicide rates in different years are characteristic. The reasons for the growth of suicide rates are unclear and cannot be explained only by better detectability (like recoding unintentional asphyxia of adolescents playing "strangulation") or by the suicidogenic effect of antidepressants. Possible explanations: increased substance abuse, depression, family and social disorganization, easier access to suicide means.

Methods of suicide.

The leading methods for adolescents are represented by self-hanging (tends to grow), self-poisoning (overdose of drugs, with an alarming trend for psychotropics) and firearms [22]. Self-suffocation is more common in children than adolescents, and knives (razors) are more often chosen by adolescents than adults. Adolescents and children who are victims of suicide are less likely to become intoxicated or have previously committed suicide attempts compared to adults [32]. A suicide by jumping from the "suicide bridges" is rare, but resonant, due to the media coverage. In geographic regions, differences are associated with access to lethal means. For instance, death as a result of jumping under trains is more common among adolescents in regions with a developed railway network, and there are apparently more self-drowning cases in settlements near rivers and waterfalls.

A studied cohort of French adolescents under 15 after a suicide attempt is also indicative: self-poisoning that required short-term hospitalization in a general hospital was chosen in $84 \%$. Suicide attempter are mostly females $(86 \%)$, less than a third of them lived in a complete family, and $27 \%$ had low school performance. Half showed "at least one psychiatric symptom" (but the other half were "mentally healthy" according to a psychiatric examination). Within a year, about $15 \%$ were hospitalized in a psychiatric hospital because of the second attempt, $21 \%$ did not receive the recommended treatment [33].

Risk factors and anti-suicidal factors.

Risk and protection factors are considered [34] for:

1) physical or biosomatic levels, including physical circumstances, genetics, health 
от причинных факторов риска, изменение которых в один момент времени предшествует и соответствует изменению СП. По этим причинам речь о потенциальной, а не фактической этиологии.

Ряд корреляций и факторов риска в литературе отнесены к этиологии, но непосредственно не тестируются. Необходим основанный на симптомах подход к выявлению потенциальных этиологических механизмов. В обзоре освещены большей частью проспективные исследования факторов риска (проспективно и позитивно связанных с суицидальными исходами) и защ̧итных (проспективно и негативно связанных с ними же). Особое внимание уделено длительным исследованиям, наиболее уместным для выявления факторов риска. Результаты организованы по степени их достоверности, а проспективные исследования и многомерный анализ квалифицируются как убедительные доказательства, подтверждённые поперечными исследованиями и / или связями. Степень доказательности не приравнена к величине эффекта: у корреляций и факторов риска довольно скромные последствия. СП сложный биопсихосоциальный и духовный феномен.

Каков путь развития СП (суицидогенез)? Какое слияние уникальных факторов заставляет подростка думать о самоубийстве, пытаться покончить с собой? Короткий и честный ответ: не знаем достаточно и точно. Несмотря на выявленные факторы, не знаем и не можем знать истинных причин СП, коли оно многопричинное. Большая часть литературы сосредоточена на коррелятах и факторах риска, полагаемых статичными без объяснений динамики риска самоубийства. Помимо внимания к индивидуальным суицидальным мыслям и СП, предстоит изучение переходов и длительности этапов суицидогенеза.

Демографические факторы.

Социально-демографические группы высокого риска СП недостаточно представлены в литературе. Например, большинство исследований СП ограничено городскими школьниками, тогда как наибольший УС у селян [26, 29, 35].

Пол представляет хорошо установленный парадокс: девушки чаще испытывают суицидальные мысли и совершают попытки самоубийства, юноши чаще погибают от суицида [36]. До 11 лет нет выраженной половой разницы распространённости или степени тяжести. Небольшие различия в возрасте начала (суицидальных мыслей женщин, более раннее начало суицидальных попыток мужчин), хотя эти модели различны в зависимости от клинической тяжести [37]. Смешаны данные о переходе от подросткового к молодому возрасту: сообщают об умеренных или постоянных групповых различиях. Различия по полу в УС молодежи, как правило, с УС взрослых, и мальчики и юноши совершают самоубийства чаще вдвое-втрое девочек и and illness;

2) mental or psychological levels, meaning mental health, self-esteem and the ability to cope with difficult circumstances, emotions or distress;

3) cultural level, or a wider living environment (social, political, environmental and economic factors that contribute to affordable options and quality of life);

4) social level: relationships and participation with people (family, friends, employees, wider community and a sense of belonging to humanity);

5) spiritual level (faith, hope, mercy, despair, salvation).

Because of the lack of experimental studies (not always possible for ethical reasons), demographic, environmental, clinical, and biological factors cannot be automatically matched with causal factors. Instead, correlates and risk factors associated (synchronized) with SB (like thoughts) or at a subsequent point in time are indicated. They differ from causal risk factors the change of which at one moment in time precedes and corresponds to the change in SB. For these reasons, we are talking about a potential, not an actual etiology.

A number of correlations and risk factors in the literature are related to etiology, but are not directly tested. A symptom-based approach is needed to identify potential etiological mechanisms. The review mostly covers prospective studies of risk factors (prospectively and positively related to suicidal outcomes) and protective (prospectively and negatively related to them). Particular attention is paid to long-term studies that are most appropriate for identifying risk factors. The results are organized according to the degree of their reliability, and prospective studies and multivariate analysis are qualified as convincing evidence, confirmed by cross-sectional studies and / or relationships. The degree of evidence is not equal to the magnitude of the effect: correlations and risk factors have rather modest consequences. SB is a complex biopsychosocial and spiritual phenomenon.

What is the path of development of SB (suicide genesis)? What combination of unique factors makes a teenager think about suicide, try to commit suicide? A short and honest answer: we don't know enough and accurately. Despite the identified factors, we do not know and cannot know the true causes of SB, since its nature is multi-cause. Most of the literature focuses on correlates and risk factors considered static without explanation of the dynamics of suicide risk. In addition to attention to individual suicidal thoughts and $\mathrm{SB}$, the study of transitions and the duration of the stages of suicide genesis is ahead.

Demographic factors. 
девушек соответственно. УС девочек в большинстве стран ниже в контрасте с частотой суицидальных мыслей и попыток с взрослением. Гендерные различия, скорее всего, обусловлены бо̀льшей вероятностью у юношей множественных факторов риска, как сопутствующие расстройства настроения и злоупотребления спиртным, более высоким уровнем агрессии и выбором смертоносных способов самоубийства. При развитии гендерных ролей в сфере труда и образования девочкиподростки (особо в восточных странах) могут сталкиваться с дополнительными стрессами.

Возраст. Большинство исследований включают подростков до 18 лет без разделения на младших и старших, что скрывает вклад нормативных сдвигов в развитии риска СП. Мало можно сказать о закономерностях периода развития без сравнения возрастных групп.

УС последовательно растёт с возрастом, возможно, из-за бо̀льшей распространённости психических расстройств у старших подростков, сочетания с злоупотреблением психоактивными веществами (ПАВ). Подростки более могут планировать и исполнить СП и показывают бо̀льшее намерение, чем младшие. У старших подростков больше самостоятельности и меньше надзора и социальной поддержки родителей. СП обусловлено развитием: суициды редки у детей и младших подростков (упомянуты статистикой Росстата с 5 лет), но риск растёт вплоть до старческого возраста. Уровень суицидальных попыток растёт по мере перехода от раннего к старшему подростковому возрасту, идёт на спад в молодости, особо у девушек.

Время пубертатных переходов служит потенциально критическим фактором подростков, поскольку, например, позднее половое созревание связано с риском самоповреждений и попыток самоубийств и после корректировки возраста и класса обучения. Как и почему это происходит (например, в мозге, роль гормональных, физических изменений) мало изучено.

Самоубийства старших подростков чаще, чем у детей и младших подростков. В разных странах УС старших подростков и молодых (15-29 лет) по меньшей мере на порядок выше, чем у детей и подростков 5-14 лет. Эта тенденция в некоторой степени объясняется большей распространённостью психопатологии, как злоупотребления ПАВ и суицидальных намерений. Различны возрастные модели выбора способа суицида.

Раса и этническая принадлежность.

Быстрый культуральный переход способствует росту УС подростков. Ассимиляция и утрата традиционных культурных практик может усилить отчуждение, конфликт поколений и создать ситуацию, в которой подросток не чувствует себя тесно связанным ни с традиционной, ни с альтернативной культурой [38]. Наиболее последовательным межнациональным выводом
Socio-demographic groups of high risk SB are not well represented in the literature. For example, most studies of SB are limited to urban schoolchildren, while villagers have higher suicide rate [26, 29, 35].

Gender presents a well-established paradox: girls are more likely to experience suicidal thoughts and attempt suicide, while boys are more likely to die from suicide [36]. Under 11 years of age, there is no marked gender difference in prevalence or severity of SB. There are slight differences in the age of onset (like, earlier onset of suicidal thoughts for women and of suicidal attempts for men), although these models differ depending on the clinical severity [37]. Data on the transition from adolescence to young age are mixed: they report moderate or permanent group differences. Differences in sex in of young people suicide rates are the same as in suicide rates for adults, with boys and men committing suicides twice or three times more often than girls and women. Suicide rates for girls in most countries are lower compared to the frequency of suicidal thoughts and attempts while growing up. Gender differences are most likely caused by the greater likelihood of multiple risk factors typical for young males, such as accompanying mood disorders and alcohol abuse, higher level of aggression and the choice of lethal suicide methods. With the development of gender roles in the working and education environment, adolescent girls (especially in eastern countries) may face additional stresses.

Age. Most studies consider adolescence a period before 18 without dividing into younger and older, which hides the contribution of regulatory shifts to the development of risk of SB. Little can be said about the laws of the development period without comparing age groups.

Suicide rates have been increasing steadily with age, possibly due to the greater prevalence of mental disorders in older adolescents, combined with substance abuse. Teenagers are more likely to plan and execute SB and show a greater intention than children. Older teens have more autonomy and less parental supervision and social support. SB is caused by development: suicides are rare in children and younger adolescents (recorded by Rosstat statistics from 5 years of age), but the risk increases up to senile age. The level of suicidal attempts increases with the transition from early to older adolescent age, is declining in youth, especially among girls.

The time of puberty transitions is a potentially critical factor for adolescents, since, for example, late puberty is associated with the risk of self-harm and attempted suicide even after adjusting the age and class of education. How and why this happens (for example, in the brain, the role of hormonal, physical 
является более высокий риск самоубийств молодежи коренных народов во всех частях мира [26]. Употребление ПАВ, бедность / безработица, легкая доступность средств суицида, травма между поколениями и потеря культуры / идентичности названы потенциальными факторами риска, а общность / семейные связи и общение названы потенциальными защитными факторами. Выводы, касающиеся иных расовых / этнических меньшинств, специфичны для региона, типа результата, связанного с самоубийством, времени.

Так, подростки-афроамериканцы реже подумывают о суициде, но устойчива тенденция роста попыток самоубийств и суицидов афроамериканцев по сравнению с белыми сверстниками, выше смертность чернокожих детей по сравнению с чернокожими подростками. Шведские дети подвержены бо̀льшему риску самоубийства, если с родителями-эмигрантами обитают в районе, где оказались меньшинством; напротив, в районах, где большая часть населения иностранцы, они защищены от риска самоубийства. Аналогичные взаимодействия между индивидуальными демографическими характеристиками и окружающей средой в группах меньшинств: испаноязычные подростки в США и южноазиатские - Соединенного Королевства $[39,40,41]$.

Суицидологические анамнез и статус.

Понимание суицидогенеза расширяет возможности групповых и индивидуальных подходов с применением широкого круга фармако- и психотерапевтических техник, научного обоснования специализированных и дифференцированных программ профилактики $\mathrm{HC}$ и СП подростков.

Суицидальные мысли подростков строго и проспрективно связаны с СП [42] и иных проблем психического здоровья в зрелые годы.

Рассматривая риск суицидальных мыслей и СП отдельно, особо следует изучить предикторы, независимо связанные с ними. Длительные исследования показали, что чем тяжелее (высока степень намерений или планирования) и интенсивнее (частота и / или продолжительность) суицидальные мысли, вероятнее их воплощение в попытку. У покушающихся с неотступными суицидальными мыслями, планом и / или сильным намерением - высок риск повторной попытки.

Предыдущая попытка суищида - сильнейший фактор риска подросткового СП в случай-контроль и проспективных исследованиях [1], повышая риск суицида в 10-60 раз [9], причём риск повторной попытки в первые 3-6 месяцев наибольший, но повышен по сравнению с общим населением не менее двух лет. УС после суицидальных попыток в 30 раз выше, чем в населении в целом; 20\% пытавшихся покончить жизнь самоубийством сделают еще одну попытку в течение первого года, и $5 \%$ погибнут от самоубийства в течение 9 лет changes) has been little studied.

Suicides are more common for older adolescents than in children and younger adolescents. In different countries, suicide rates of older adolescents and young people (15-29 years old) are higher than that of children and younger adolescents aged 5-14. This tendency is to some extent explained by the greater prevalence of psychopathology as substance abuse and suicidal intentions. The choice of the method of suicide is also different for different ages.

Race and ethnicity. A rapid cultural transition contributes to the growth of the adolescent suicide rates. The assimilation and loss of traditional cultural practices can strengthen estrangement, generational conflict and create a situation in which a teenager does not feel closely connected with either traditional or alternative culture [38]. The most consistent international conclusion is a higher risk of suicide among indigenous youth in all parts of the world [26]. Substance abuse, poverty / unemployment, easy access to suicide means, intergenerational trauma, and loss of culture / identity are identified as potential risk factors, and community / family relationships and communication are identified as potential protective factors. Conclusions regarding other racial / ethnic minorities are specific to the region, such as suicide-related outcomes of time.

Thus, African-American teenagers are less likely to think about suicide, but there is a steady tendency in increase of suicide attempts and suicides of African-Americans in comparison to their white peers, mortality of black children is higher compared to black teenagers. Swedish children are at greater risk of suicide if they live with an emigrant parent in an area where they are a minority; on the contrary, in areas where most of the population is foreign, they are protected from the risk of suicide. Similar interactions are observed between individual demographic characteristics and the environment in minority groups: Hispanic teens in the United States and South Asian teens in the United Kingdom [39, 40, 41].

Suicidological history and status.

Understanding suicide genesis expands the possibilities of group and individual approaches using a wide range of pharmaco- and psychotherapeutic techniques, the scientific justification of specialized and differentiated programs for the prevention of NSSH and CB adolescents. Suicidal thoughts of adolescents are strictly and prospectively associated with SB [42] and other mental health problems in adulthood.

Considering the risk of suicidal thoughts and SB separately, it is especially necessary to study the predictors that are independently associated with them. Long-term studies have 
[43]. Подросток с опытом суицидальной попытки, возможно, полагает, что нашёл универсальный способ ухода от жизненных неблагоприятных событий с приобретённым опытом и при снижении барьера страха.

Несуицидальные самоповреждения (НС) подростка - важный предиктор его повтора, СП, психических расстройств [17], как формируемого пограничного расстройства личности и расстройств приёма пищи.

Мысли о самоповреждениях и НС могут предшествовать «истинному» СП, а НС или попытки самоубийства - самоубийству.

\section{Намерение и мотивачия.}

Суицидальное намерение (выраженность стремления) умереть - мощная дискриминантная и прогностическая переменная рецидива СП: состоит из четырёх переменных: 1) убеждённость в намерении; 2) подготовка попытки; 3) предотвращение обнаружения (помощи); и 4) взаимодействие [44].

Критерии, различающие «завершителей и покушающихся», включают доказательства планирования, выбор времени попытки во избежание обнаружения, заблаговременное раскрытие суицидальных планов и выражение желания умереть.

Мотивачия - «причина СП», указанная жертвой и / или его близкими. Для трети покушающихся с высоким суицидальным намерением - умереть или навсегда избежать (убежать от) психосоциального дистресса (неблагоприятной жизненной ситуации). У таких подростков особо высок риск повторных попыток самоубийств. Мотивы СП указывают недостаток социальных навыков.

Триггер. Наиболее распространёнными фасадными поводами СП подростков служат межличностные конфликты или потери, особо злоупотребляющих ПАВ. Раздор (ссора) - фактор риска самоубийств и попыток. Чем более «неразрешимы» разногласия, тем вероятнее повторная попытка. При расстройствах поведения и употреблении ПАВ правовые и дисциплинарные проблемы - общие причины СП, отражая вклад импульсивности, агрессии и употребление ПАВ в суицидальный риск.

Взаимосвязанное рискованное поведение. СП чаще сопутствует другим видам рискованного для здоровья и отчасти окружающих поведения, как обжорство, пьянство, курение, ношение оружия и незащищённый секс [45]. Среди более 11 тыс. школьников 14-16 лет в 10 странах ЕЭС употребление спиртного (13\%), курение табака (31\%), физическая гиподинамия (33\%), патологическое потребление интернета (4\%), сон менее 8 часов. Психологические факторы, как депрессия, тревога, низкая самооценка, безнадежность и слабые социальные сети связаны с СП подростков в странах с разным уровнем дохода [1]. Общими факторами риска оказались поверхностная связь родителей и подростка shown that the more severe (high degree of intentions or planning) and more intense (frequency and / or duration) suicidal thoughts are, the more likely they lead to an attempt. Attempts with persistent suicidal thoughts, plan, and / or strong intention have a high risk of reoccurrence.

The previous suicide attempt is the strongest risk factor for adolescent SB in casecontrol and prospective studies [1], increasing the risk of suicide 10-60 times [9], and the risk of retrying in the first 3-6 months is greatest, but increased compared to the total a population for at least two years. Suicide rates after a suicide attempt is 30 times higher than in the general population; $20 \%$ of suicide attempters will make another attempt in the first year, and $5 \%$ will die from suicide within 9 years [43]. A teenager with experience of suicidal attempt may think that he has found a universal way of avoiding life's adverse events with acquired experience and while lowering the fear barrier.

Non-suicidal self-harm (NSSH) of a teenager is an important predictor of suicide repetition, SB, mental disorders [17], as a formed borderline personality disorder and eating disorders.

Thoughts about self-harm and NSSH can precede a "true" SB, while thoughts about selfharm and suicide attempts can precede suicide.

Intention and motivation.

Suicidal intention to die (the severity of the desire) is a powerful discriminant and prognostic variable for relapse of SB. It is made up of four variables: 1) assurance of intention; 2) preparation of the attempt; 3) prevention of detection (assistance); and 4) interaction [44].

Criteria that distinguish between suicide committers and attempters include evidence of planning, timing of attempts to avoid detection, early disclosure of suicidal plans, and expression of desire to die.

Motivation is the cause of SB that the victim and / or their relatives reported. A third of the attempters with high suicidal intent reports it to be the desire to die or to forever avoid (run away from) psychosocial distress (adverse life situation). Such adolescents are particularly at high risk of repeated suicide attempts. SB motives indicate a lack of social skills.

Trigger. The most common facade causes of SB of adolescents are interpersonal conflicts or losses, especially substance abuse. Discord (quarrel) is a risk factor for suicides and attempts. The more "unsolvable" the discord is, the higher the risk of another attempt is. In case of behavioral disorders and substance abuse, legal and disciplinary problems are common causes of SB reflecting the contribution of impulsiveness, aggression and substance abuse to suicidal risk. 
(безнадзорность), подростка и школы при тяготении к девиантным сверстникам [46].

Аффективные, когнитивные и социальные факторы риска СП измерены через самоотчёты, поведение и патофизиологические пробы. Аффективные относятся бо̀льшей частью к негативному аффекту. Когнитивные - к управлению импульсами (импульсивности) и отражают искажения обработки информации. Социальные - к вовлечённости в межличностные отношения. Негативные аффективные процессы наиболее доказательно поддержаны исследованиями как факторы риска СП, а когнитивные и социальные факторы (процессы) - умеренно.

Личностные / психологические факторы.

Импульсивность и / или агрессия. Агрессия занимает ведущее место в суицидогенезе. Так, вербальная и физическая агрессия связана с попытками суицида подростков [47]. Агрессивность как личностная черта и внешнее выражение гнева связаны с риском суицида депрессивных мальчиков. Импульсивная агрессия как психологическая черта - ответ на разочарование или провокацию, предрасполагая к СП; вовлечена в феноменологию, нейробиологию и семейную передачу СП. Большая доля детей и подростков, совершивших самоубийство, проявляли агрессивное поведение, не зависящее от депрессии. Подростки могут быть более импульсивны при принятии решений и сосредоточиться на ближайших последствиях поведения, но не отдалённых целях. Импульсивное поведение подростков провоцирует трудности как поводы дистресса или СП. Так, импульсивность и агрессия усложняют общение, школьные проблемы и соблюдение закона. Метафора подростка: спортивный авто с турбо-заряженными чувствами при слабых навыках вождения. Связь импульсивности и СП подростков ослаблена контролем безнадёжности, невротизма, внешнего локуса контроля, самооценки и экстраверсии [9]. Для предотвращения незапланированных самоубийств в импульсивной подгруппе следует ограничить доступ к средствам суицида.

Импульсивность, обычно по самоотчётам, умеренно подтверждена исследователями как фактор риска СП подростков и молодых [48]. Возможно, связь импульсивности с суицидальными мыслями слаба, но в сочетании с агрессией (импульсивной агрессии) корреляция более надёжна и фактор риска силён. Импульсивность предсказывает семейную передачу суицидального риска («суицидальное послание») [49] и дополняют исследования гнева и агрессии как проспективных факторов риска СП особо у подростков мужского пола и при перекрытии с регуляцией эмоций, «яростной» руминацией, снижением самоконтроля.

Невротизм - тенденция реагировать на угрозу, разочарование и потерю негативным аффектом; личностная склонность переживать более широкий спектр
Interconnected risky behavior. SB is often accompanied by other types of behaviors that are risky for their own health and for others, such as gluttony, drunkenness, smoking, carrying weapons and unprotected sex [45]. Among more than 11 thousand schoolchildren aged 14-16, in 10 countries of the European Union, drinking alcohol (13\%), smoking tobacco $(31 \%)$, physical inactivity $(33 \%)$, pathological Internet consumption (4\%), sleep less than 8 hours. Psychological factors such as depression, anxiety, low self-esteem, hopelessness and weak social networks are associated with adolescent SB in countries with different income levels [1]. The common risk factors turned out to be the superficial connection between the teen and their parents (neglect), the teen and their school especially if a teen is inclined to deviant peers [46].

Affective, cognitive, and social risk factors for SB are measured through self-reports, behavior, and pathophysiological tests. Affective factors are mostly related to negative affect. Cognitive factors relate to control impulses (impulsiveness) and reflect the distortion of information processing. Social factors suggest involvement in interpersonal relationships. Negative affective processes are most conclusively supported by research as the highest risk factors for SB, while cognitive and social factors (processes) are supported moderately.

Personal / psychological factors.

Impulsivity and / or aggression. Aggression takes a leading place in suicide genesis. For instance, verbal and physical aggression is associated with teenage suicide attempts [47]. Aggressiveness as a personality trait and an outward expression of anger are associated with suicide risk for depressed boys. Impulsive aggression as a psychological trait is a response to disappointment or provocation, predisposing to $\mathrm{SB}$; involved in phenomenology, neurobiology and family transmission of SB. A large proportion of children and adolescents who committed suicide showed aggressive behavior that did not depend on depression. Adolescents may be more impulsive when making decisions and tend to focus on immediate consequences of behavior rather than distant goals. Impulsive behavior of adolescents provokes difficulties as it causes distress or SB. Impulsiveness and aggression complicate communication, aggravate school problems and can lead to problems with law. The following metaphor can describe a teenager: a sports car with turbo-charged feelings and poor driving skills. The connection between impulsiveness and SB in adolescents is weakened by the control of hopelessness, neurotism, the external locus of control, selfesteem and extraversion [9]. To prevent unplanned suicides in an impulsive subgroup, access to suicide means should be limited. 
негативных эмоций, долгое время в ответ на дистресс [9] - служит значимым фактором риска СП при исключении других факторов риска, предиктором регоспитализации в течении года в связи с СП.

Негативная аффективность, личностная черта, характеризующаяся склонностью к длительному и выраженному негативному аффекту в ответ на стресс, выделена в качестве личностной предиспозиции СП [50] после контроля других факторов риска.

Низкая самооценка прогнозирует попытки самоубийств подростков, но связь слабеет после контроля депрессии и безнадёжности [51].

Перфекиионизм. Не обнаружено связи с самоубийством, но нереально высокие ожидания служат фактором риска СП подростков; связь ослаблена контролем психопатологии. У подростков, совершивших попытку самоубийства, социально приписываемый перфекционизм не связан с безнадёжностью в отличие от Яадресованного перфекционизма и склонностью критиковать себя. Перфекционистские стандарты самопрезентации (потребность казаться идеальным) и социально приписываемый перфекционизм детей и подростков тесно связаны с буллингом и социальной безнадёжностью («нет надежды на удовлетворяющие отношения») и, в итоге, с СП [52, 53].

Недостаточная стрессоустойчивость свойственна подросткам - суицидентам. Выделены особые паттерны совладания подростков с девиантным поведением и антивитальным настроением: избегание, фокус на негативных аспектах и переживаниях, отказ от желаний, отрицание. Подростки с предпочтением эмоционально-сфокусированного стиля в стрессе и фрустрации неэффективно планируют жизнь, разрешают типовые проблемы, они более депрессивны. Девушки более полагаются на эмоционально-сфокусированный копинг и руминацию, выражение эмоций, тогда как юноши более склонны к отвлечению. Проблемно - фокусированный копинг реже используется подростками с историей импульсивных попыток суицида, склонными предоставить проблеме разрешиться самой, «выбросить её из головы» [54]. Конфронтация и дистанцирование более выражены у суицидентов [55] в сочетании с недостаточными навыками планирования решения проблемы, позитивной переоценки, самоконтроля и поиска социальной поддержки.

Напротив, позитивные навыки совладания связаны с более лёгкой депрессией, меньшей выраженностью активных суицидальных мыслей и намерений; проблемно-ориентированный стиль совладания негативно связан с депрессией в общем населении и клинической выборке. Отсюда стратегии совладания и их изменение служат важной мишенью профилактики СП. Стратегии самоконтроля, принятия ответственности, планирования решения проблем и позитивной переоценки более
Impulsivity, usually based on self-reports, is moderately confirmed by researchers as a risk factor for adolescent and young adults [48]. Perhaps the connection between impulsivity and suicidal thoughts is weak, but in combination with aggression (impulsive aggression), the correlation is more reliable and the risk factor is strong. Impulsivity predicts the family transmission of suicidal risk ("suicidal message") [49] and complement studies of anger and aggression as prospective risk factors for SB especially in male adolescents and when overlapping with the regulation of emotions, "furious" rumination, and decreased in self-control.

Neurotism is the tendency to respond to threat, disappointment, and loss by negative affect; personal tendency to experience a wider range of negative emotions, a long time in response to distress [9] works as a significant risk factor for SB excluding other risk factors, a predictor of rehospitalization during the year due to SB.

Negative affectiveness, a personality trait characterized by a tendency to prolonged and pronounced negative affect in response to stress, is highlighted as a personal predisposition of SB [50] after checking other risk factors.

Low self-esteem predicts suicide attempts by adolescents, but the relationship weakens after controlling for depression and hopelessness [51].

Perfectionism. No association with suicide was found, but unrealistically high expectations are a risk factor for adolescent SB; association is weakened after psychopathology control. In adolescents who attempted suicide, socially attributed perfectionism is not associated with hopelessness, unlike self-addressed perfectionism and a tendency to criticize oneself. Perfectionist standards of self-presentation (the need to seem ideal) and the socially attributed perfectionism of children and adolescents are closely related to bullying and social hopelessness ("there is no hope for a satisfying relationship") and, as a result, to SB [52, 53].

Insufficient stress resistance is characteristic of adolescent suicides. Special patterns of coping with adolescent behavior and anti-vital mood are highlighted: avoidance, focus on negative aspects and feelings, rejection of desires, denial. Teenagers with preference of an emotionally focused style in stress and frustration do not plan their lives efficiently, solve typical problems, they are more depressed. Girls are more likely to rely on emotionally focused coping and rumination, expression of emotions, while boys are more prone to distraction. Problem-focused coping is less commonly used by adolescents with a history of impulsive suicide attempts, who are inclined to let the problem resolve itself, "throw it out of my head" [54]. Confrontation 
используются подростками без СП.

Сексуальная ориентация и гендерная идентичность. Предполагаемые факторы, опосредующие связь между ориентацией геев, лесбиянок и бисексуалов (GLB) и самоубийства, включают клинический уровень расстройств настроения и злоупотребления ПАВ, виктимизацию и отвержение семьи.

Юные лесбиянки, геи, бисексуалы, трансгендеры и «колеблющиеся» демонстрирует более высокую частоту СП, чем гетеросексуальный контроль [56] и после учёта депрессии, безнадёжности, злоупотребления алкоголем и недавней виктимизации в школе и дома.

Бремя сексуального меньшинства зависит от социальной среды и степени поддержки местных ЛГБТ сообществ. Юные ЛГБТ подвержены на 20\% большему риску попытки самоубийства в «неподходящем районе» с редкостью однополых союзов в школах; отсутствием школьных программ борьбы с издевательствами и дискриминацией учащихся - ЛГБ [57].

Несмотря на доказательства повышенного риска СП секс меньшинств, группа указана в менее $2 \%$ длительных исследований факторов риска суицида.

Клинические факторы / психические расстройства.

Бо́льшая часть литературы сосредоточена на клинических факторах риска СП [58, 59]. Психиатрические диагнозы помогают выявить группы высокого риска, но они разнородны, и сложно объяснить, как и почему возникает риск СП. У 90\% подростков, жертв самоубийств (как и в старших возрастах, по данным ВОЗ) выявлены (обычно ретроспективно) психические расстройства, в 9 раз выше риск суицида; 80\% попыток суицида - на фоне психопатологических симптомов.

Хроническое течение и тяжесть расстройств повышают риск самоубийств. Сильнейшим фактором риска СП служит невыявленное и нелеченное (адекватно) психическое расстройство.

СП подростков - проблема «пограничной» психиатрии: лишь $5 \%$ суицидов и попыток на фоне психозов, когда нельзя утверждать истинное СП. Около $1 / 4$ детей и подростков страдают от поведенческих и психических расстройств, дебют которых приходится на эти годы. Почти 30\% 15-летних девушек и $13 \%$ сверстников - юношей в Европе признались о «плохом настроении» чаще, чем раз в неделю; каждый 10-й подросток к 15летнему возрасту (9\% девушек и $16 \%$ юношей) регулярно употреблял алкоголь не реже раза в неделю [3].

При депрессии, зависимости ПАВ и шизофрении риск самоубийств особо высок в первый год верификации диагноза [60], что объяснимо осознанием психического расстройства и его последствий (ограничением возможностей, распадом «Я»). В этой связи необходимы фаза-специфические программы профилактики СП, например, в клиниках первого эпизода болезни. Подро- and distancing are more pronounced among suicide attempters [55] in combination with insufficient skills in planning a solution to a problem, positive re-evaluation, self-control, and the search for social support.

On the contrary, positive coping skills are associated with milder depression, less pronounced active suicidal thoughts and intentions; a problem-oriented coping style is negatively associated with depression in the general population and clinical sample. Hence, coping strategies and their changes are an important target for the prevention of SB. The strategies of selfcontrol, acceptance of responsibility, problemsolving planning and positive re-evaluation are more used by adolescents without SB.

Sexual orientation and gender identity. Perceived factors mediating the relationship between gay, lesbian, and bisexual (GLB) orientation and suicide include the clinical level of mood disorders and substance abuse, victimization, and family rejection.

Young lesbians, gays, bisexuals, transgender people and "hesitant" show a higher incidence of SB than heterosexual control [56] when analyzing depression, hopelessness, alcohol abuse and recent victimization at school and at home.

The burden of the sexual minority depends on the social environment and the degree of support for local LGBT communities. Young LGBT people are at a $20 \%$ greater risk of attempted suicide in an "unsuitable neighborhood," with the rarity of same-sex unions in schools; the lack of school programs to fight bullying and discrimination of LGB students [57].

Despite evidence of an increased risk of $\mathrm{SB}$ of sex minorities, the group is listed in less than $2 \%$ of long-term studies of suicide risk factors.

Clinical factors / mental disorders.

Most of the literature focuses on clinical risk factors for SB [58, 59]. Psychiatric diagnoses help identify high-risk groups, but they are heterogeneous, and it is difficult to explain how and why the risk of SB arises. $90 \%$ of adolescents, victims of suicide (according to the WHO, in older ages as well) have psychiatric disorders (usually retrospectively), have 9 times higher risk of suicide; $80 \%$ of suicide attempts happen with psychopathological symptoms in the background.

The chronic course and severity of the disorder increase the risk of suicide. The strongest risk factor for SB is an undiagnosed and untreated (adequately) mental disorder.

Adolescent SB is a problem of "borderline" psychiatry: only $5 \%$ of suicides and attempts happen at psychoses when it is impossible to state the true SB. About $1 / 4$ children and adolescents suffer from behavioral and 
стки с психотическими симптомами, знающие о расстройстве, но типовой помощи, в 20 раз более склонны к самоубийству, чем ищущие её [61].

Способность наблюдать и регулировать эмоции важна для переживания негативного и позитивного аффекта. Длительные исследования показали, что эмоциональная дисрегуляция связана с СП подростков. Трудность определения эмоций и ограничений эффективных стратегий регуляции предсказывают попытку суицида при контроле исходных депрессивных симптомов [62].

Ограниченные стратегии регуляции эмоций более прогностически значимы, чем трудности идентификации эмоций. Особые подходы к регуляции эмоций, дезадаптивные когнитивные стратегии, как умственная жвачка (руминация) и подавление негативных мыслей и чувств, связаны с суицидальными мыслями подростков и молодых взрослых [63].

Адаптивные стратегии юных, как отвлечение внимания и решение проблем выявляют многообещающие антисуицидальные факторы и более предсказуемы, чем дезадаптивные [63], как гибкость стратегий регуляции эмоций (подавление или выражение эмоций)

Личностные расстройства - сильный потенциальный личностный предиктор СП, особо при декомпенсации. Психологические аутопсии указывают расстройства личности у жертв самоубийств. В контролируемом исследовании расстройство личности связано с 2,9 раз большим риском самоубийств и 8,5-кратно - с диссоциальными, пограничными, истерическими, нарциссическими расстройствами после контроля настроения, употребления ПАВ [9].

Важной составляющей в патогенезе СП служит выраженность импульсивности, эмоциональной нестабильности, склонности к аутоагрессии. Данным поведенческим и аффективным паттернам в МКБ соответствуют пограничная и нарциссическая личностные диспозиции. Пограничный тип характеризуется постоянной тревогой, ощущением брошенности и импульсивными поступками, нередко с СП. Самоповреждающее поведение проявляется в азартных играх, транжирстве, употреблении ПАВ как проявления хронической суицидальности. Расстройства социального поведения связаны с 36 кратно большим риском самоубийств подростков и вероятнее ведут к СП при злоупотреблении ПАВ.

Аффективные расстройства увеличивают риск СП обоих полов, по длительным исследованиям. Депрессия - ведущая причина СП подростков. Риск суицида депрессивных подростков 8-30\% [9]. По психологическим аутопсиям около 60\% подростков соответствовали критериям депрессивного расстройства (DSMIV) при суициде [49]. У 90\% лиц с расстройствами настроения в детском возрасте в анамнезе выявляются различные формы суицидального поведения; у 63\% - mental disorders, the onset of which falls on these years. Almost 30\% of 15-year-old girls and $13 \%$ of young males in Europe admitted to being "in a bad mood" more than once a week; every 10th teenager by the age of 15 ( $9 \%$ of girls and $16 \%$ of young men) regularly consumed alcohol at least once a week [3].

The risk of suicide is especially high in the first year of verification of the diagnosis for depression, substances abuse and schizophrenia [60], which is explained by awareness of mental disorder and its consequences (limited ability, disintegration of self). In this regard, phasespecific programs for the prevention of SB are necessary, for example, in clinics of the first episode of the disease. Adolescents with psychotic symptoms, who are aware of the disorder and its typical care, are 20 times more likely to commit suicide than those who seek it [61].

The ability to observe and regulate emotions is important for experiencing negative and positive affect. Long-term studies have shown that emotional dysregulation is associated with adolescent SB. The difficulty in determining the emotions and limitations of effective regulatory strategies is predicted by suicide attempts to control the initial depressive symptoms [62].

Limited strategies for regulating emotions are more predictive than the difficulties of identifying emotions. Special approaches to the regulation of emotions, maladaptive cognitive strategies, like mental chewing (rumination) and suppression of negative thoughts and feelings, are associated with suicidal thoughts of adolescents and young adults [63].

Adaptive strategies of young people, such as distraction and problem solving, reveal promising anti-suicidal factors and are more predictable than maladaptive ones [63], as the flexibility of strategies for regulating emotions (suppression or expression of emotions)

Personality disorders are a strong potential personality predictor of SB, especially with decompensation. Psychological autopsies indicate personality disorders in suicide victims. In a controlled study, personality disorder is associated with a 2.9-fold higher risk of suicide and 8.5-fold higher risk of dissocial, borderline, hysterical, narcissistic disorders after mood control, and substance abuse [9].

An important component in the pathogenesis of SB is the severity of impulsivity, emotional instability, and a tendency to autoaggression. These behavioral and affective patterns in the ICD correspond to borderline and narcissistic personality dispositions. The border type is characterized by constant anxiety, a feeling of abandonment and impulsive actions, often with SB. Self-harming behavior is manifested in gambling, shopping sprees, substance abuse as manifestations of chronic 
прошлые попытки самоубийства. В ходе последующего наблюдения $40 \%$ пациентов демонстрируют суицидальное поведение; 7\% сообщают о попытках самоубийства [64].

В проспективном исследовании «случай-контроль» взрослых, страдающих клинической депрессией с подросткового возраста в течение 10 лет и более $8 \%$ самоубийств против $0 \%$ «здоровых» (без депрессий в анамнезе и ныне) при пятикратном росте риска первой попытки самоубийства [65].

Депрессия ухудшает социальное, семейное, функционирование, школьную успеваемость, сопряжена с риском возврата, злоупотреблением ПАВ (частое средство самолечения), то есть усугубляет факторы риска СП и НС. Большинство детей и подростков с субсиндромальной депрессией (от части из-за переживаний безнадёжности и никчемности) не получает профессиональной помощи.

Однако утверждение, что депрессия - фактор риска СП, мало проясняет этиологию из-за многочисленных сочетаний депрессивных симптомов, подтипов, траекторий и сопутствующих заболеваний. Важно выделение черт «суицидальной» депрессии. Наиболее частые атрибуты СП депрессивных подростков: безнадёжность, бесперспективность, переживания заброшенности, ненужности, одиночества от пассивного, психологически понятного уровня до навязчивых и сверхценных образований. Распространена жалоба на «скуку», пустоту жизни (которую порой наполняют асоциально) в рамках антивитального настроения. Депрессивные ощущение бесполезности и низкая самооценка как показатели негативного самореферентного мышления предсказывают СП при контроле других симптомов депрессии и исходного СП [63].

Безнадёжность - пессимистичный взгляд на будущее, в котором не ожидаешь лучшего, при беспомощности перед неизбежными неблагоприятными событиями, наряду с дефицитом навыков решения и неспособностью опираться на жизненный опыт. Безнадёжность как следствие дисфункциональных эмоциональных связей с родителями и низкого социально-экономического положения семьи (для девочек важнее первые, для мальчиков второе) способствует СП и НС [66]. Риск СП подростка возрастает, если в структуре депрессии переживание безнадёжности, а семья дисфункциональна, то есть, проблематична неформальная поддержка [67].

При контроле психопатологии (обычно депрессии), безнадёжность свойственна подросткам с «хроническими» суицидальными мыслями [68], причем безнадёжность - более важный предиктор СП, чем депрессия. Подросткам с суицидальными попытками, в отличие от размышляющих о суициде, свойственны выраженные переживания безнадёжности, одиночества при нежелании обсуждать переживания. Безнадёжность - suicidality. Disorders of social behavior are associated with a 3-6-fold greater risk of suicides in adolescents and are more likely to lead to SB in case of substance abuse.

Affective disorders increase the risk of $\mathrm{SB}$ for both sexes, according to longitude studies. Depression is a leading cause of SB in adolescents. The risk of suicide of depressed teenagers is $8-30 \%$ [9]. According to psychological autopsy, about $60 \%$ of adolescents met the criteria for Depressive Disorder (DSM-IV) in case of suicide [49]. In 90\% of people with mood disorders in childhood, a history of various forms of suicidal behavior is observed; $63 \%$ have past suicide attempts. During follow-up, $40 \%$ of patients demonstrate suicidal behavior; 7\% report suicide attempts [64].

In a prospective case-control study of adults suffering from clinical depression from adolescence for 10 years and more, there are reported to be $8 \%$ of suicides versus $0 \%$ of "healthy" ones (no history of depression today) with a five-fold increase in the risk of the first attempt - killing [65].

Depression worsens social and family functioning, school performance, is associated with a risk of reoccurrence, substance abuse (a frequent means of self-medication), that is, aggravates the risk factors of SB and NSSH. Most children and adolescents with low depression (partly due to feelings of hopelessness and worthlessness) do not receive professional assistance.

However, stating that depression is a risk factor for SB does not make clear the etiology as there are numerous combinations of depressive symptoms, their subtypes, trajectories, and comorbid diseases. It is important to highlight the features of "suicidal" depression. The most common attributes of SB of depressed adolescents are hopelessness, feelings of abandonment, uselessness, loneliness that can take different degrees from passive, psychologically understandable to obsessive and overvalued. It is common to hear complaints about "boredom", the emptiness of life (which is sometimes filled with asocial behavior) but it is part of the anti-vital mood. Depressive feelings of uselessness and low self-esteem as indicators of negative self-referential thinking predict SB when controlling other symptoms of depression and the initial SB [63].

Hopelessness is a pessimistic view of the future when one does not expect better things to come, feels helpless when facing inevitable adverse events, and lacks decision skills and ability to rely on life experience. Hopelessness comes as a result of dysfunctional emotional relationships with parents and the low socioeconomic situation of the family (the first is more important for females, and the second matters for males) and contributes to SB and 
предиктор повторного СП подростков обоих полов разных стран [69]. Подростки, совершившие попытку самоубийства, указывают связь безнадёжности с рядом дисфункциональных личностных характеристик («заторможенность» и «сенситивность») неспособностью регулировать аффект и негативной самооценкой.

Шкала безнадёжности Бека - инструмент скрининга подростков в общей медицинской и психиатрической практике в её двухмерной версии - шкалы надежды и безнадёжности. Однако безнадёжность - важнейший духовный фактор, - лишь дистальный фактор риска, не предсказывая СП при контроле истории попыток самоубийства и депрессия в отличие от молодых взрослых.

Ангедония - осевой депрессивный симптом, по МКБ-10, прогнозирует суицидальные попытки при контроле изначальных суицидальных мыслей, сексуальных травм, пограничного личностного расстройства [50].

Бессонница (нарушения цикла сна-бодрствования) распространена у депрессивных как проявление соматического синдрома [70]; нарушает суждения подростков, концентрацию внимания, контроль импульсов, способствуя СП.

Биполярное расстройство II типа (не выделено МКБ-10), смешанные состояния увеличивают риск попыток.

Тревожное расстройство связано с СП подростков, хотя в некоторых исследованиях его вклад в суицидальный риск уменьшается при учёте аффективных расстройств, но панические атаки могут увеличить риск СП и после такого контроля.

Расстройства пищевого поведения. Частота самоубийств подростков 14-25 лет, страдающих нервной анорексией, в 8 раз превышает таковую в общем населении, особо при сочетании с диссоциальными, пограничными, истерическими, нарциссическими расстройствами [71]. Расстройство пищевого поведения связано с повышенным риском тяжелых попыток самоубийств, а у девочек, совершивших попытки самоубийства, чаще такие расстройства [46].

Посттравматическое стрессовое расстройство $(П T C P)$. Данные психологической аутопсии не сообщают о частоте ПТСР. Однако ПТСР повышает риск СП школьников и после учёта пола и депрессии. В продольном исследовании раннее (14 лет) начало ПТСР связано с попытками самоубийств в течение жизни, но не обнаружено одновременной ассоциации [13]. Связь ПТСР и СП с клинической депрессией в течение жизни, по-видимому, опосредована частотой коморбидностью расстройств личности с диссоциальными, пограничными, истерическими, нарциссическими расстройствами.

Употребление ПАВ (алкоголь / иные наркотики) порой как средство самолечения, играет значительную роль в СП, особо старших подростков мужского пола с
NSSH [66]. The risk of adolescent SB increases if the structure of depression is experiencing hopelessness and the family is dysfunctional, that is, informal support is problematic [67].

When controlling psychopathology (usually depression), hopelessness is characteristic of adolescents with "chronic" suicidal thoughts [68], and it is a more important predictor of SB than depression. Adolescents with suicidal attempts, in contrast to those with suicide ideation, are characterized by pronounced experiences of hopelessness, loneliness and unwillingness to discuss experiences. Hopelessness is a predictor of another attempt for adolescents of both sexes in different countries [69]. Adolescents who attempted suicide indicate a particular connection between hopelessness and a number of dysfunctional personality characteristics ("lethargy" and "sensitivity"), the inability to regulate affect and low self-esteem.

The Beck Hopelessness Scale is a screening tool for adolescents in general medical and psychiatric practice in its two-dimensional version - the hope and hopelessness scale. However, even though hopelessness is the most important spiritual factor, it is only a distal risk factor, not predicting SB when monitoring the history of suicide attempts and depression, in contrast to young adults.

Anhedonia, an axial depressive symptom, according to ICD-10, predicts suicidal attempts to control initial suicidal thoughts, sexual trauma, and borderline personality disorder [50].

Insomnia (disturbances in the sleep-wake cycle) is common among depressed people as a manifestation of the somatic syndrome [70]; distorts adolescents judgments, concentration, impulse control, contributing to SB.

Type II bipolar disorder (ICD-10 is not isolated), mixed conditions increase the risk of attempts.

Anxiety disorder is associated with adolescent SB, although in some studies its contribution to suicidal risk is reduced when affective disorders are taken care of, panic attacks can increase the risk of SB after such control.

Eating Disorders. The suicide rate of adolescents aged 14-25 suffering from anorexia nervosa is 8 times higher than that in the general population, especially when combined with dissocial, borderline, hysterical, narcissistic disorders [71]. Eating disorder is associated with an increased risk of severe suicide attempts, and girls who have committed suicide attempts are more likely to have these disorders [46].

Post-Traumatic Stress Disorder (PTSD). Psychological autopsy data do not report the 
сопутствущими аффективным расстройством или нарушением социального поведения. Пытающиеся покончить с собой чаще употребляют ПАВ, чем размышляющие о суициде «идеаторы»: возможно, употребление ПАВ способствует переходу от идеи к действию. У $18-36 \%$ употребляющих ПАВ подростков отмечено СП; употребление ПАВ в 3-4 раза повышает риск суицидальных попыток, в 5-13 раз вероятнее зависимые подростки гибнут от суицида [69]; 15-50\% молодых суицидентов страдали зависимостью от ПАВ. Употребление ПАВ (как проявление хронического суицида, по К. Меннингеру), и СП - взаимосвязанные проблемы. Функционально у них, возможно, общие факторы риска, уязвимости и защиты. Так, хронический дистресс, как конфликт в семье, служит триггером для СП и употребления ПАВ. Подросток пытается убить себя, чтобы избежать семейных проблем. Он же уязвим к употреблению ПАВ для «самолечения» или бегства от неприятных ощущений и / или проблем. Злоупотребление ПАВ указывает модели предпочтений, как использование синтетических каннабиноидов в уязвимых группах подростков из числа сексуальных меньшинств и с сопутствующими психическими расстройствами [72].

Психоз. Больные подвержены повышенному риску СП. Отнесение СП психотического больного к «истинному» суициду (как допускала А. Амбрумова) или несчастному случаю - предмет дискуссии, затуманивающей точность эпидемиологического анализа.

Расстройства шизофренического спектра. В СП подростков типичны амбивалентность, суицидальные мысли скрываются от окружающих [6]. Мотивы самоповреждений больных шизофренией подростков следующие: «неопредёленная угроза» (переживания интенсивного качественно неопределённого страха по типу надвигающейся катастрофы, тремы, по Конраду; «угроза личностного опустошения и деградации» (переживание нарастающей психической дезорганизации); «изменение самоощущения» (переживание собственной изменённости); «первичная утрата смысла жизни» (переживание бесцельности и бессмысленности собственного существования) [73].

Психиатрическая коморбидность. Психологическая аутопсия показала, что до $70 \%$ молодых жертв самоубийств страдали сопутствующими расстройствами, причём риск самоубийства увеличивается с их количеством [49]. Сочетание (кумуляция рисков) расстройств настроения и поведения, злоупотребления ПАВ особо суицидоопасна. Жертвы самоубийств обычно страдают психическими и / или физическими расстройствами, но факторы риска не обязательно присутствуют в каждом случае и отличаются в странах, на индивидуальном уровне в зависимости от культурных, политических, (духовных) и экономических особенностей. incidence of PTSD. However, PTSD increases the risk of schoolchildren with SB after if gender and depression are considered. In a longitudinal study, the early (14 years) onset of PTSD was associated with suicide attempts during life, but no simultaneous association was found [13]. The association of PTSD and SB with clinical depression throughout life is apparently mediated by the frequency of comorbidity of personality disorders with dissocial, borderline, hysterical, narcissistic disorders.

Substance abuse (alcohol / other drugs), sometimes as a means of self-medication, plays a significant role in SB, especially for older male adolescents with comorbid affective disorder or a social behavior disorder. Those who try to commit suicide are more likely to abuse substances than those with suicide ideation - possibly substance abuse facilitates the transition from idea to action. In $18-36 \%$ of adolescents with substance abuse, SB was noted; substance abuse increases the risk of suicide attempts 3-4 times, and addicted adolescents die from suicide 5-13 times more likely [69]; $15-50 \%$ of young suicides were addicted. Substance abuse (as a manifestation of chronic suicide, according to $\mathrm{K}$. Menninger) and SB are interrelated problems. Functionally, they may have common risk, vulnerability, and protection factors. So, chronic distress, as a conflict in the family, serves as a trigger for SB and substance abuse. A teenager is trying to kill himself to avoid family problems. He is also vulnerable to addictions for "self-medication" or flight from discomfort and / or problems. Substance abuse indicates preference models, such as the use of synthetic cannabinoids in vulnerable groups of teenagers from sexual minorities and with comorbid mental disorders [72].

Psychosis. Patients are at increased risk for SB. The attribution of a psychotic patient's SB to "true" suicide (as A. Ambrumova admitted) or an accident is a matter of discussion that obscures the accuracy of the epidemiological analysis.

Schizophrenic spectrum disorders. In adolescent SB ambivalence is typical, suicidal thoughts are hidden from others [6]. The motives for self-harm of teenagers with schizophrenia are the following: "an undetermined threat" (experiencing intense qualitatively indefinite fear as an impending catastrophe, trema according to Konrad; "threatening personal devastation and degradation" (experiencing increasing mental disorganization); "change of self-awareness" (experiencing one's own change); "primary loss of the meaning of life" (experiencing the aimlessness and senselessness of one's own existence) [73].

Psychiatric comorbidity. Psychological autopsy showed that up to $70 \%$ of young vic- 
СП «здоровых», без явного психического расстройства и / или употребления ПАВ: $40 \%$ жертв суицида до 16 лет были «здоровы» при паттерне более низкого намерения и большей доступности средства суицида, истории СП, проблемах с законом и дисциплиной. Лишь $1 / 4$ жертв суицида до 12 лет соответствовали критериям психиатрического диагноза, но у $30 \%$ депрессивные симптомы (речь о субсиндромальной депрессии) [74]. Формализация СП как диагностической категории облегчает организационную проблему, но данные сводят на нет клиническую значимость СП как цель лишь медицинского вмешательства.

Клинические факторы / телесные болезни. Хроническая боль и функциональные ограничения связаны с СП даже после учета других факторов риска. Возможна связь СП с конкретными хроническими болезнями, как сахарный диабет и рак [75]. У подростка нет выстраданного опыта преодоления мучительных болезней, поиска ресурсов помощи. Диагноз тяжелой медицинской болезни может привести к обрыву мало ценимой (как при изначальной депрессии) жизни. К типу хронического суицида примыкает отказ от необходимого лечения.

Когнитивные нарушения могут быть привязаны к возрастному периоду, выходя за нормативные рамки и / или быть выражением психического и / или соматического расстройства (как депрессии, зависимости от ПАВ) и / или нежелательным действием лекарств (способствует уклонению от лечения). Поведенческие задачи лучше выявляют подростков, пытавшихся совершить самоубийство, чем самоотчёты [9]. У пытающихся совершить самоубийство дефицит устойчивого внимания (типичная жалоба депрессивного подростка на «рассеянность») и бдительности, то есть сети предупреждения внимания [76] без групповых различий в ориентирующих, исполнительных сетях внимания. У пытавшихся покончить с собой подростков автобиографические воспоминания чрезмерно обобщены и неспецифичны, независимо от эмоциональной окраски [77], но возможно их искажение, питающее экстрапунитивность (обвинения близких в «неправильном воспитании», притеснениях).

Социальные факторы / процессы. Подростки учатся договариваться со сверстниками при меньшем участии и контроле взрослых, менее полагаются на поддержку старших и больше на сверстников. Стремясь к отношениям вне семьи, они чувствительны к мнению сверстников, что повышает уровень стресса, риск отвержения и, опосредованно, СП. Подростки учатся романтическим и любовным отношениям, и их разрыв увеличивает риск СП [78]. К наиболее распространённым социальным процессам относится межличностная связь, например, одиночество.

Социальная изоляция (одиночество) может играть центральную роль, опосредуя связь социальной тревоги и последующих суицидальных мыслей подростков tims of suicide suffered from comorbid disorders, and the risk of suicide increases with their number [49]. The combination (cumulation of risks) of mood disorders and behaviors, substance abuse is especially suicidal. Suicide victims usually suffer from mental and / or physical disorders, but risk factors are not necessarily present in each case and differ in countries, on an individual level, depending on cultural, political, (spiritual) and economic characteristics.

SB of "healthy" adolescents who didn't report any obvious mental disorder and / or substance abuse is characteristic of the following $-40 \%$ of suicide victims under 16 years of age were "healthy" with a pattern of lower intent and greater accessibility to suicide, history of SB, problems with law and discipline. Only $1 / 4$ victims of suicide over 12 met the criteria for a psychiatric diagnosis, $30 \%$ had depressive symptoms (talking about subsyndromal depression) [74]. Formalization of SB as a diagnostic category facilitates the organizational problem, but the data negate the clinical significance of SB as the goal of only medical intervention.

Clinical factors / somatic diseases. Chronic pain and functional limitations are associated with SB even after taking other risk factors into account. A possible association of SB with specific chronic diseases such as diabetes mellitus and cancer [75]. Teenagers do not have an experience of overcoming painful diseases or searching for resources of help. A diagnosis of a serious medical illness can lead to a break in life that is of little value (as with the initial depression). The type of chronic suicide is associated with the rejection of the necessary treatment.

Cognitive impairment can be associated with the age period, going beyond the normative framework and / or be an expression of a mental and / or somatic disorder (such as depression, substance addiction) and / or undesirable effects of medication (contributes to avoidance of treatment). Behavioral tasks identify adolescents who tried to commit suicide better than self-reports [9]. Attempts to commit suicide have a deficit of sustained attention (a typical complaint of a depressed teenager about "distraction") and alertness, that is, attention warning networks [76] without group differences in orienting, executive attention networks. Autobiographical memories of adolescents who attempted suicide are overly generalized and nonspecific, irrespective of emotional coloring [77], but they can be distorted as it nourishes their extrapunitivity (accusations of relatives of "improper upbringing", oppression).

Social factors / processes. Adolescents learn to negotiate with peers and involvement 
или попыток самоубийств уже во взрослом возрасте. Это важный длительный предиктор подростковой депрессии и суицидальных мыслей [79]. Умеренные доказательства одиночества как прямого и непосредственного фактора риска СП подростков. Влияние одиночества на СП подростков опосредовано психопатологией. У подростков с неразвитыми социальными навыками вследствие искажённых отношений с родителями в детстве - трудности установления приятельских отношений. Неспособность удовлетворить потребность в личных контактах ведёт к одиночеству. Безнадёжность и одиночество связаны с СП и порознь, но особо при их сочетании [10].

Особенностями социального взаимодействия пытающихся покончить с собой подростков служат паттерны просодических и качественных особенностей голоса, например, с придыханием, что позволяет их дистанционное выявление и обучение посредством машинного обучения динамическим компонентам просодии и вокализации [80]. В будущих длительных исследованиях важно разграничить переживания одиночества и депрессивные симптомы для большей прогностической ценности.

Неблагоприятные (стрессогенные) жизненные события суицидентом-подростком воспринимаются невыносимыми и непреодолимыми. Не менее $60 \%$ родителей сообщают, что их ребёнок пережил стрессовый конфликт до суицида, обычно не воспринимаемый окружающими (взрослыми) как трагедийный. Они стыдятся, когда, ему указывают на проступок и унижают его достоинство. Подросток болезненно реагирует на комментарии по этому поводу, стыд - мучительно переносимое чувство, а в сочетании с личностными чертами уязвимости и импульсивности, может оказаться опасным. Отсюда самоубийство может представлять попытку ребенка «смыть позор» [81].

Конфликт межличностных отношений. По данным посмертных психолого-психиатрических экспертиз, трети самоубийств юных предшествует серьёзный конфликт отношений в последние две недели жизни или такой конфликт предсказуем в следующие две недели. Оставшиеся в живых часто указывают, что конфликт личных отношений ускорил попытку суицида [82].

«Дрейф». Подростки без естественных ресурсов поддержки (друзья, близкие), подвержены высокому риску самоубийства, особо в контексте других факторов риска, способствующих «дрейфующему» статусу. Жизнь без родителей - фактор риска попытки самоубийства даже после учёта других факторов риска. Увеличен риск попыток самоубийств школьников на грани отчисления и среди бросивших учение, а также принятых вновь и наоборот, положительная связь со школой и академическими достижениями защищает от СП [83].

Трудности учёбы и давление несведущих в душевных проблемах подопечных учителей - один из глав- and control of adults goes down, less rely on support from adults and more on support from peers. Seeking relationships outside the family, they are sensitive to peers' opinions, which increases stress levels, the risk of rejection and, indirectly, SB. Adolescents get involved into first romantic and love relationships and breaking them up increases the risk of SB [78]. The most common social processes include interpersonal communication, for example, loneliness.

Social exclusion (loneliness) can play a central role, mediating the connection of social anxiety and subsequent suicidal thoughts of adolescents or suicide attempts in adulthood. This is an important long-term predictor of teenage depression and suicidal ideation [79]. There is slight evidence of loneliness as a direct and immediate risk factor for adolescent SB. The effect of loneliness on adolescent SB is mediated by psychopathology. Adolescents with undeveloped social skills due to distorted relationships with parents in childhood have difficulty establishing friendships. Failure to meet the need for personal contacts leads to loneliness. Hopelessness and loneliness are associated with SB and separately, but especially when combined [10].

The features of social interaction of teenagers trying to commit suicide are patterns of prosodic and qualitative voice features, for example, aspirated, which allows their remote identification and training through machine learning of the dynamic components of prosody and vocalization [80]. In future long-term studies, it is important to distinguish between feelings of loneliness and depressive symptoms for greater predictive value.

Unfavorable (stressful) life events by a suicidal teenager are perceived as unbearable and insurmountable. At least $60 \%$ of parents report that their child experienced a stressful conflict before suicide, which is usually not perceived as tragic by others (adults). Teenagers are ashamed when, they are told to misconduct and their dignity is humiliated. A teenager reacts painfully to comments on this subject; shame is a painfully tolerable feeling, and in combination with personality traits of vulnerability and impulsivity, it can be dangerous. Hence, suicide may represent a child's attempt to "wash away the shame" [81].

Conflict of interpersonal relationships. According to post-mortem psychological and psychiatric examinations, a third of young suicides are preceded by a serious conflict of relationship in the last two weeks of life, or such a conflict is predictable in the next two weeks. Survivors often indicate that a conflict of personal relations hastened suicide attempt [82].

"Drifting". Adolescents without natural support resources (friends, relatives) are at 
ных факторов риска СП уязвимых подростков $[82,84]$ в связи, с чем нужно целевое обучение «вахтеров» из числа школьных учителей и психологов.

Частые переезды. Независимо от детскородительского конфликта, подростки 11-17 лет чаще совершали попытки самоубийства [85]. Вероятность суицида переехавшего подростка 3-5 раз и более 10 - в 2,3 и в 3,3 раз выше соответственно, чем у оседлых», тогда как у тех, кто переехал более чем 10 раз в 3,3 раза больше шансов совершить самоубийство [86]. Изменения школы, класса, потеря «ближнего круга» приятелей - служит дистрессом и обедняет (временно?) неформальную сеть поддержки.

Семейные факторы риска и корреляции.

Наиболее убедительны доказательства средового риска, связанного с жестоким обращением и издевательствами в детстве. Неоднозначны свидетельство влияния сверстников и СМИ на кластерные самоубийства. Предварительны данные о сроках (экспозиции) жестокого обращения в раннем возрасте, нетрадиционных формах виктимизации сверстниками (киберзапугивания) и влияния через интернет.

Искажение семейной структуры. Размывание семейных ценностей, низкая сплочённость, дезадаптивные эмоциональные коммуникации усиливают дисфункциональный потенциал семьи и способствуют увеличению деструктивности, направленной вовне и / или обращённой подростком на самого себя. Жертвы самоубийств вероятнее из «повреждённых» семей, хотя связь развода и СП может быть объяснена повышенным уровнем психопатологии родителей, чьи браки распались. Связь СП с крушением брака родителей может быть опосредована иными психосоциальными факторами риска, как хроническим конфликтом в семье, низким уровнем привязанности [87].

У депрессивных подростков недостаточное взаимодействие семьи и семейные конфликты служат предикторами попыток самоубийства в течение года после оценки. Небрежение в воспитании повышает риск СП подростка [88]. Формально полная, но разобщённая семья, заражённая консюмеризмом, может казаться благополучной («сиротство при живых родителях», по Б.С. Положему), но и гиперопека препятствуют формированию независимости, своего «Я».

Родительская психопатология как депрессия, злоупотребление ПАВ служит фактором риска СП и после контроля психопатологии подростков.

Семейное СП. Усыновление, исследования близнецов и семей убедительно доказывают, что СП является семейным и, возможно, генетическим, склонность к СП передаётся в семьях независимо от психических расстройств как таковых. У пробандов с попыткой самоубийства повышен риск самоубийства в семье, а у пробандов, совершивших суицид, повышен риск попытки, high risk of suicide, especially in the context of other risk factors that contribute to a "drifting" status. Life without parents is a risk factor for attempted suicide even after taking care of other risk factors. The risk of attempting suicide is increased for schoolchildren on the verge of expulsion and among those who dropped out of school, as well as those who are accepted again and on the contrary, a positive connection with the school and academic achievements protects against SB [83]. Difficulties of studies and the pressure of mentees who are ignorant of the mental problems are one of the main risk factors for vulnerable teenagers $[82,84]$ and requires targeted training for school teachers and psychologists.

Frequent relocations. Regardless of the parent-child conflict, adolescents aged 11-17 made suicide attempts more often [85]. The likelihood of suicide of a teenager who has moved is 3-5 times is 2.3 times higher compared to settled teens, and those who moved more than 10 times are 3.3 times more likely to commit suicide [86]. Changes in school, class, the loss of the "inner circle" of friends serves as a distress and impoverishes (temporarily?) the informal support network.

Family risk factors and correlations.

The most convincing is evidence of environmental risk associated with child abuse and bullying. The evidence of peer and media influence on cluster suicides is ambiguous. The data on the timing (exposure) of abuse at an early age, non-traditional forms of victimization by peers (cyberbullying) and influence via the Internet is yet under analysis.

Distortion of family structure. The corruption of family values, low cohesion, and maladaptive emotional communications increase the dysfunctional potential of the family and contribute to an increase in destructiveness directed outward and / or turned by the teenager towards himself. Suicide victims are more likely to come from distorted families, although the connection between divorce and SB can be explained by the increased level of psychopathology of the parents whose marriages have broken up. The relationship between SB and the collapse of the parents' marriage can be mediated by other psychosocial risk factors, such as a chronic conflict in the family and a low level of attachment [87].

In depressed teens, inadequate family interactions and family conflicts are predictors of suicide attempts within a year of evaluation. Neglect in bringing-up increases the risk of adolescent SB [88]. A formally complete, but fragmented family infected with consumerism may seem prosperous ("orphaning with living parents," according to B.S. Polozhyi), but hyperprotection also hinders the formation of independence and Self. 
подтверждая мнение, что передаваемый фенотип был склонностью к СП, отличным по смертельности [89].

У родственников жертв самоубийств среди подростков в 2-6 раз выше частота СП, даже при учёте психопатологии родственников и потомков. Показано 5-6кратное увеличение риска попыток самоубийств потомков их совершивших, независимо от депрессии и иной психопатологии. Возможно, «раннее» СП именно семейное. Передача СП от родителя ребёнку опосредована импульсивной агрессией как поведенческим эндофенотипом, описывающим генетический диатез СП [90, 91].

Потеря родителя из-за смерти или развода (особо до 12 лет), жизнь отдельно от родителей служит фактором риска СП. У друзей, братьев и сестёр подростков, совершивших самоубийства, повышен риск депрессии, не СП, но при длительном наблюдении, постоянное травматическое горе было обычным явлением и ассоциировалось с пятикратно бо̀льшей вероятностью суицидальных мыслей при контроле депрессии [92].

Семейные раздоры связаны с подростковым СП, но эффект ослаблен контролем родительской и пробандной психопатологии. Качество отношений родителей и детей также важный фактор СП. Отсутствие родителей - важный фактор риска подросткового СП. Распад (дисфункция) семьи из-за раздоров, насилия вызывает суицидальные мысли подростка [93].

Ухудшение отношений с родителями (родителем) наиболее распространены как предвестники самоубийств. Паттерн, демонстрирующий последовательное продвижение к СП, может быть следующим. Подростки сталкиваются с одной или несколькими проблемами, ведущими к чувству одиночества и обременённости, мыслям, планам или попыткам самоубийств. Постоянное воздействие негативных переживаний и мыслей / планов о самоубийстве и / или самоповреждающих действий ведёт к самоубийству [94].

Жестокое обращение в детстве: сексуальное, физическое и эмоциональное насилие, предсказывают суицидальные мысли и попытки самоубийства молодежи. Проспективные когортные исследования и изучение близнецов показали уникальное влияние сексуального насилия на попытки самоубийства и смерть подростков и молодых, независимо от контекстуальных факторов, как характеристики родителей и детей и качество семейного окружения [95]. Агрессия родителей влечёт СП детей и подростков. Риск попытки самоубийства в 6 раз выше у женщин и в 8 раз у мужчин из семей с домашним насилием [96].

Физическое и сексуальное насилие тесно связаны с СП $[90,97]$ независимо, живут ли они дома или в психиатрически учреждениях, правонарушители, бездомны. Связь физического и сексуального насилия в детстве с попытками самоубийства подростка не зависят от пола, возраста, расы или этнической принадлежно-
Parental psychopathology such as depression, substance abuse, serves as a risk factor for SB even after controlling the psychopathology of adolescents.

Family SB. Adoption, studies of twins and families convincingly prove that SB is familial and, possibly, genetic; the tendency to SB is transmitted in families regardless of mental disorders as such. Probands with attempted suicide have an increased risk of suicide in the family, and probands who commit suicide have an increased risk of attempt, confirming the view that the transmitted phenotype was prone to SB, different in mortality [89].

Relatives of adolescent suicide victims have 2-6 times higher incidence of SB, even when the psychopathology of relatives and descendants is taken care of. A 5-6-fold increase in the risk of suicide attempts is shown for descendants of suicide attempters, regardless of depression and other psychopathology. It is possible that when SB is observed at young age it is simply a family trait. Transmission of SB from parent to child is mediated by impulsive aggression as a behavioral endophenotype describing the genetic diathesis of SB [90, 91].

Loss of a parent due to death or divorce (especially before 12), as well as living separately from parents is a risk factor for SB. Friends, brothers and sisters of teenagers who commit suicide have an increased risk of depression, not SB, but with long-term followup, constant traumatic grief was common and was associated with a five-fold greater likelihood of suicidal thoughts in controlling depression [92].

Family contention is associated with adolescent SB, but the effect is weakened by the control of parental and proband psychopathology. The quality of parent-child relationships is also an important factor in SB. Lack of parents is an important risk factor for adolescent SB. Disintegration (dysfunction) of the family due to contention, violence causes suicidal thoughts of a teenager [93].

Deteriorating relationships with parents (parent) are most common of suicide predictors. A pattern demonstrating consistent progress towards SB may be the following. Adolescents face one or more problems leading to feelings of loneliness and burden, thoughts, plans, or suicide attempts. The constant impact of negative feelings and thoughts / plans for suicide and / or self-harming actions leads to suicide [94].

Child abuse: sexual, physical and emotional abuse predict suicidal thoughts and youth suicide attempts. Prospective cohort studies and the study of twins showed the unique impact of sexual violence on the attempted suicide and death of adolescents and young people, regardless of contextual factors, 
сти, семейного социально-экономического статуса или уровня образования опекуна; сохраняется независимо от психологического стресса в детстве и в раннем подростковом возрасте, депрессии, рискованного поведения, сопутствующих интернализующих и экстернализующих симптомов и предыдущих попыток самоубийства [90] истории СП, психических расстройств и злоупотребления ПАВ в семье [97]. Физическое и сексуальное насилие в детстве сочетаются и независимо связаны с повторными попытками самоубийства при контроле других неблагоприятных факторов детства [98].

Не менее $1,5 \%$ студентов и $8,4 \%$ студенток США подверглись изнасилованию членами семьи. Инцест связан с СП детей и подростков [99]. У сексуального насилия более долгосрочные последствия, чем физическое [90], будучи сильнейшим фактором риска СП $[100,101]$ независимо от социально - экономического статуса семьи, диссоциативных симптомов молодежи, негативных жизненных событий, симптомов психического здоровья, разлуки с близкими, тюремного заключения, уровня образования и изменения в попечителе. Риск попытки самоубийства в 15 раз выше у подростков мужского пола, ставших жертвами сексуального насилия, чем девочек [102].

Популяционный аттрибутивный риск (PAR) попыток самоубийства подростков в популяционных исследованиях 16,6-19,5\%, причем гораздо выше риск СП после сексуального насилия [87]. Хотя основное влияние сексуального насилия на СП опосредовано риском психопатологии [90], возможен независимый эффект для риска и ранней попытки самоубийства, даже после контроля повышения риска психопатологии и других факторов [46].

Эмоциональное насилие менее изучено, но и повышает вероятность суицидальных мыслей детей старшего возраста и подростков при контроле истории суицидальных мыслей, депрессивных симптомов, а иногда коварианты контролируют сексуальное и физическое насилие [103]. Эмоциональное насилие, а не пренебрежение к потребностям ребёнка (воспитанию), связано с СП независимо от проблем с психическим здоровьем, иными семейными переменными [104].

При кумуляции всех типов насилия попытки самоубийства подростков, в первую очередь, связаны с сексуальным и эмоциональным. В систематическом обзоpe $[105,106]$ отношение шансов попыток самоубийства 3,4 для физического и эмоционального насилия и 2 для пренебрежения.

Исследования (отдельные опираются на поперечный дизайн и / или ретроспективный самоотчёт) смещены в сторону выявления временных характеристик жестокого обращения (то есть начала первого контакта, возникновения воздействия в течение определённого периода развития), связанных с СП. Получены сме- such as the characteristics of parents and children and the quality of the family environment [95]. Aggression of parents entails SB of children and adolescents. The risk of suicide attempt is 6 times higher in women and 8 times in men from families with domestic violence [96].

Physical and sexual violence are closely related to SB $[90,97]$ regardless of whether they live at home or in psychiatric institutions, are offenders or homeless. The relationship of physical and sexual violence in childhood with teenage suicide attempts does not depend on gender, age, race or ethnicity, family socioeconomic status or educational level of the guardian; it stays regardless of psychological stress in childhood and early adolescence, depression, risky behavior, comorbid internalizing and externalizing symptoms and previous suicide attempts [90], the history of SB, mental disorders and substance abuse in the family [97]. Physical and sexual violence in childhood are combined and are independently associated with repeated suicide attempts in the control of other adverse childhood factors [98].

At least $1.5 \%$ of male and $8.4 \%$ of female students in the United States were raped by family members. Incest is associated with SB of children and adolescents [99]. Sexual violence has more long-term consequences than physical [90], being the strongest risk factor for SB [100, 101], regardless of the socioeconomic status of the family, dissociative symptoms of youth, negative life events, symptoms of mental health, separation from relatives, imprisonment, level of education and change in trustee. The risk of suicide attempt is 15 times higher in male adolescents who are victims of sexual violence than girls [102].

The population attributive risk (PAR) of teenage suicide attempts in population studies is $16.6-19.5 \%$, with a much higher risk of SBafter sexual abuse [87]. Although the main influence of sexual violence on SB is mediated by the risk of psychopathology [90], an independent effect is possible for risk and early suicide attempts, even after controlling the increase in the risk of psychopathology and other factors [46].

Emotional violence is less studied, but it also increases the likelihood of suicidal thoughts in older children and adolescents when controlling the history of suicidal thoughts, depressive symptoms, and sometimes covariant control sexual and physical violence [103]. Emotional violence, and not neglect of the child's needs (upbringing), is associated with SB regardless of mental health problems or other family variables [104].

Of all types of violence, suicide attempts by adolescents are primarily associated with sexual and emotional types primarily. In a systematic review [105, 106], the ratio of 
шанные данные относительно чувствительных периодов воздействия жестокого обращения, причём некоторые подчеркивали влияние в середине подросткового возраста или в дошкольные годы и раннем детстве [107]. Некоторые факторы зависят от пола или типа жестокого обращения.

Буллинг (преследование сверстниками). Активное запугивание (вербальное, реляционное, физическое) связано с СП подростков отделения неотложной помощи. Длительные исследования показали влияние социального исключения, словесного / физического жестокого обращения и принуждения сверстниками в детстве и раннем подростковом возрасте на позднейшее СП [108] при контроле депрессии и других психиатрических симптомов и особо прочны для преследуемых подростков-девочек. Длительность преследований служит ключевым фактором увеличения риска СП. Преступники и его жертва, свидетели травли составляют группу риска СП [109].

Запугивание - редко единственный фактор, способствующий СП, но результат взаимодействия биологических, психологических и социальных факторов. У подростков, подвергающихся издевательствам, обратная связь между СП и обращением за помощью. Для известных жертв издевательств внезапное и необъяснимое прекращение жалоб на издевательства или отрицание предыдущих страданий может быть признаком риска самоубийства.

Кластеры и «заражение» СП. Малое, но статистически значимое число самоубийств и попыток происходит в пространственно - временных кластерах, согласно механизмам заражения и имитации [110] и ограничены подростками и молодыми. Самоидентификация коренится в нормах группы сверстников, увеличивая риски поведенческих и эмоциональных нарушений, включая СП. Так, сверстники могут имитировать или моделировать СП. Временно-пространственные кластерные суициды (то есть точечные кластеры) распространены у подростков 15-19лет, реже старше 24 лет.

Некое объяснение кластеров в теории социального обучения (Social learning theory) поддержано длительными исследованиями. Подросток, друг жертвы суицида (попытки) - группе риска СП [46] и в осложнённом горевании, социальной интеграции в виде ассертивных отношений (сходно уязвимые индивиды тянутся друг к другу и сходно восприимчивы к жизненному дистрессу [111].

Влияние СМИ. Массовые кластеры, суициды, часто посредством СМИ, связаны, но отличны от точечных кластеров. Менее доказательны данные о массовых кластерах, чем точечных. Показаны кластеры СП в разных странах вслед широко растиражированного суицида [112]. Факторы, повышающие вероятность подражания, включают степень публичности и извест- chances of suicide attempts is 3.4 for the physical and emotional

Studies (some are based on a transverse design and / or retrospective self-report) are biased towards revealing the temporal characteristics of ill-treatment (that is, the onset of the first contact, the occurrence of exposure during a certain period of development) associated with SB. Mixed data were obtained regarding sensitive periods of exposure to abuse, with some emphasizing the influence in the middle of adolescence or in pre-school years and early childhood [107]. Some factors depend on gender or type of abuse.

Bullying (chasing by peers). Active bullying (verbal, relational, physical) is associated with SB in adolescents in the emergency department. Long-term studies have shown the effects of social exclusion, verbal / physical abuse and coercion by peers in childhood and early adolescence on late SB [108] in controlling depression and other psychiatric symptoms and are particularly strong for targeted teenage girls. The duration of the persecution is a key factor in increasing the risk of SB. The criminals and their victim, witnesses of bullying constitute a risk group for SB [109].

Intimidation is rarely the only factor contributing to $\mathrm{SB}$, but the result of the interaction of biological, psychological and social factors. Bullying teens have an inverse relationship between SB and seeking help. For famous victims of child abuse, a sudden and unexplained termination of complaints of bullying or denial of previous suffering may be a risk of suicide.

Clusters and "contingency" of SB. A small but statistically significant number of suicides and attempts occurs in spatiotemporal clusters, according to contingency and imitation mechanisms [110] and are restricted to adolescents and young people. Self - identification is rooted in the norms of a group of peers, increasing the risks of behavioral and emotional disorders, including SB. So, peers can imitate or model SB. Temporary spatial cluster suicides (i.e. point clusters) are common in adolescents aged 15-19 and happen less often after 24 years of age.

A certain explanation of the clusters in the theory of social learning (Social learning theory) is supported by lengthy research. A teenager, a friend of a suicide victim (attempter) is at risk for SB [46] because of complicated grief, social integration in the form of assertive relationships as similarly vulnerable individuals are drawn to each other and are similarly susceptible to life distress [111].

The influence of the media. Suicides in mass clusters are often connected through the media, but they are different from point clusters. Data on mass clusters is less convincing than on point clusters. The clusters of SB in different 
ности жертвы. Представление самоубийства в фактическом свете (объяснение психическим расстройством) по сравнению с романтической интерпретацией связано с более низким риском имитации. Имитация зависит от метода СП (выбор «модного»).

Проспективные исследования не указывают роста случаев СП друзей жертв самоубийств, сверстниковподростков, при повышенном риске депрессии и ПТСР. Однако в поперечном исследовании [113] сверстников китайских подростков, совершивших попытки и самоубийство, выше показатели СП даже после учёта возраста, пола и факторов потенциального риска. Недавняя попытка самоубийства друга служит важным предиктором попытки самоубийства «выжившего» особо при «ассортивной» привязанности с учётом депрессии и психосоциальных факторов риска.

Интернет служит основным источником информации о СП (методах, общение), и чрезмерное потребление интернета может содействовать уязвимым подросткам осуществить СП. Ряд стран блокируют просуицидные вебсайты. Позитивный эффект Сети в помощи и поддержке [114].

Киберзапугивание похоже на традиционное запугивание и часто происходит одновременно с ним, но с помощью электронных устройств, как мобильные телефоны или компьютеры. Другие отличительные особенности киберзапугивания включают анонимность преступника, потенциальную частоту и хроничность преследования (например, возможность запугивания сутками напролёт). У киберзапугивания, возможно, даже более сильные эффекты, чем у традиционных форм. Преследователи и жертвы киберзапугивания в группе риска СП. Исследования показывают, что у испытавших киберзапугивание, риск самоповреждений повышается в 2,3 раза, а риск суицидальной попытки в 2,5 раза. Сами киберзапугивающие преступники, хоть и в меньшей степени, но так же подвержены суицидальному риску (в 1,2 раза) [115].

Зависимость от Сети, кибербуллинг повышают риск СП, будучи связаны с депрессией, иными психическими расстройствами и наоборот. Подростки с СП используют интернет как средство совладания с дистрессом, поднятия настроения. Зависимые с трудом выполняют учебные и социальные обязанности, склонны к избегающему и жесткому стилю совладания как СП при столкновении с жизненными дистрессами. Зависимость от Сети, возможно, связана с психическим расстройством, и малолетние душевнобольные изгои используют Сеть как суррогат общения.

У Сети потенциально вредоносный и защитный (антисуицидальный) потенциалы влияния на $\mathrm{HC}$ и СП (табл. 1). Сложная природа социальных сетей, НС и СП требует комплексного подхода. Потенциал интернета как среды антикризисных мероприятий неоднозначен, но в целом разновозрастные участники оценили его положительно. countries are shown after widely propagated suicide [112]. Factors that increase the likelihood of imitation include the degree of publicity and popularity of the victim. Presentation of suicide in an actual light (explanation of mental disorder) compared with a romantic interpretation is associated with a lower risk of imitation. Simulation depends on the method of SB (the choice of a "fashionable" one).

Prospective studies do not indicate an increase in cases of SB among friends of suicide victims, teenage peers, with an increased risk of depression and PTSD. However, in a crosssectional study [113] of peers of Chinese adolescents who attempted and committed suicide, the SB indicators are higher even after considering age, gender and potential risk factors. A recent suicide attempt by a friend is an important predictor of the suicide attempt of a "survivor", especially with "assortment" attachment, taking into account depression and psychosocial risk factors.

The Internet is the main source of information about SB (methods, communication), and excessive consumption of the Internet can provoke SB in vulnerable adolescents. A number of countries block prosuicide websites. There is positive effect of the Network in helping and supporting as well [114].

Cyberbullying is similar to traditional bullying and often occurs simultaneously with it, but using electronic devices like mobile phones or computers. Other distinctive features of cyberbullying include the anonymity of the offender, the potential frequency and the chronicle of the persecution (for example, the possibility of bullying for days and nights). Cyberbullying may have even more powerful effects than traditional bullying forms. Persecutors and victims of cyberbullying are at risk for SB. Studies show that in those who experience cyberbullying, the risk of self-harm is increased by 2.3 times, and the risk of suicide attempt increases 2.5 times. The cyberintimidating criminals themselves, although to a lesser extent, are also exposed to suicidal risk (1.2 times) [115].

Network addiction, cyberbullying increases the risk of SB being associated with depression, other mental disorders and vice versa. Adolescents with SB use the Internet as a means of coping with distress, raising their spirits. They hardly carry out educational and social duties, are prone to the avoiding and tough styles of coping as SB when faced with life distress. Addiction to the Web may be related to mental illness, and young mentally ill outcasts use the Web as a substitute for communication.

The Network has potentially harmful and protective (anti-suicidal) potentials of influence on NSSH and SB (Table 1). 
Неоднозначное влияние интернет-среды [110]*

Таблица 1 / Table 1

The ambiguous impact of the Internet environment [110]*

\begin{tabular}{c|c|c}
\hline \multirow{2}{*}{ Среда / Environment } & \multicolumn{2}{|c}{ Влияне / Influence } \\
\cline { 2 - 3 } & Положительное / Positive & \multicolumn{2}{|c}{ Отрицательное / Negative } \\
\hline & Умеренное использование Сети свя- & Нормализация намеренных самоповреждений.
\end{tabular}
зано с меньшим риском для психического здоровья подростков, чем малое и чрезмерное. Потенциально защитное влияние низкого уровня использования по сравнению с его

Общее

использование интернета General use of the Internet отсутствием. Информация о ресурсах кризисной помощи.

Moderate use of the Internet is associated with less risk to the mental health of adolescents than small and excessive use of it. Low use might have potentially protective effect compared to its absence. Information on crisis assistance resources.

\section{Интернет} зависимость Internet addiction Sources of assistance

Социальные сети** Social media

\section{Форумы**}

Forums

Общение и удовлетворенность жизнью «зависимых».

Communication and satisfaction with the life of "addicts".

Онлайн мониторинг депрессии и
суицидального риска; доступная когнитивно-поведенческая терапия (депрессии).

Online monitoring of depression and suicide risk; affordable cognitive behavioral therapy (depression).

Поиск неформальной помощи и поддержки, общение с товарищами по несчастью, облегчение гнева и разочарования. Сообщение о бедственном положении («крик о помощи») до / после НС и СП.

Seeking informal help and support, communicating with fellow sufferers, and alleviating anger and frustration. Reporting distress ("cry for help") before / after NSSH and SB.

Уменьшение изоляции. Поддержка психического здоровья, совладание с дистрессом, снижение риска суицидальных мыслей. Онлайн диагностика риска НС и СП.

Decrease of isolation. Mental health support, coping with distress, reducing the risk of suicidal thoughts. Online diagnosis of the risk of NSSH and SB.

Просуицидные сайты

Pro-suicide websites

Поиск помощи

Seeking help
Облегчённое распространение информации о

СП; отдельные и кластерные самоубийства уязвимых подростков. Активное использование $(\geq$ 2 часов в день) связано с низкой самооценкой психического здоровья, неудовлетворенной потребностью его поддержки, психологическим дистрессом и учащением суицидальных мыслей. Normalization of intentional self-harm. Facilitated dissemination of information about SB; single and cluster suicides of vulnerable adolescents. Active use ( $\geq 2$ hours per day) is associated with low selfevaluation of mental health, unsatisfied need for its support, psychological distress and increased suicidal thoughts.

Неясный вектор причинно-следственной связи (коли есть) с НС и СП жертв и преследователей.

An unclear vector of causal relationship (if any) between NSSH and SB of victims and offenders.

Стрессогенные электронные письма побуждают решать проблемы самостоятельно.

Stressful emails encourage you to solve problems on their own.

Поощрение (прославление) и нормализация НС и СП. Стрессогенные сообщения связаны с СП уязвимых подростков.

Encouragement (glorification) and normalization of NSSH and SB. Stressful messages associated with SB of vulnerable adolescents.

Поощрение планов самоубийств. Детальные предложения метода самоубийства. Нормализация самоповреждений и обсуждение способов их сокрытия. Влияние на риск НС неясно.

Promotion of suicide plans. Detailed suggestions of the suicide method. Normalization of self-harm and discussion of ways to conceal them. Impact on NSSH risk is unclear.

Нормализация и укрепление намерения НС и СП. Поиск единомышленников для суицидального договора.

Normalization and strengthening of intentions of NSSH and SB. Search for like-minded people for a suicidal contract.

Неизвестно

Unknown

сайты

Возможная польза

Possible use 
Таблица 1 (продолжение) / Table 1

\begin{tabular}{|c|c|c|}
\hline $\begin{array}{l}\text { Обмен } \\
\text { видео- } \\
\text { изображениями** }\end{array}$ & $\begin{array}{l}\text { Осведомленность о СП в дискримини- } \\
\text { рованных и избегающих помощи груп- } \\
\text { пах. Альтернатива или сдерживающий } \\
\text { фактор самоповреждений. Обмен опы- } \\
\text { том совладания с дистрессом. } \\
\text { Awareness of SP in discriminated groups } \\
\text { that avoid help. An alternative or deter- } \\
\text { rent to self-harm. Exchange of experience } \\
\text { in coping with distress. }\end{array}$ & $\begin{array}{l}\text { Комментарии и просмотр для поддержания, побу- } \\
\text { ждения к (подражательному) самоповреждению. } \\
\text { «Картинки» как триггер СП. Ощущение «соревно- } \\
\text { вания» кто и что хуже. Обмен опытом дезадаптив- } \\
\text { ного совладания с дистрессом. } \\
\text { Comments and viewing to maintain, induce (imitative) } \\
\text { self-harm. "Pictures" as a SB trigger. The feeling of } \\
\text { "competition" who and what is worse. Exchange of } \\
\text { experience of maladaptive coping with distress. }\end{array}$ \\
\hline $\begin{array}{l}\text { Блоги** } \\
\text { Blogs }\end{array}$ & $\begin{array}{l}\text { Неизвестно } \\
\text { Unknown }\end{array}$ & $\begin{array}{l}\text { Распространение потенциально вредоносной ин- } \\
\text { формации: ухищрений утаивания самоповрежде- } \\
\text { ний и методов самоубийств. } \\
\text { Spreading potentially harmful information: tricks to } \\
\text { hide self-harm and suicide. }\end{array}$ \\
\hline
\end{tabular}

*B систематических обзорах сопоставимо соотношение исследований с положительными и отрицательными результатами. Эмпирические исследования ограничены при расширении анализа воздействий Сети. **Исследования социальных сетей, форумов, обмена видеоизображениями, блогами меньше и хуже качеством со смешанными результатами / * In systematic reviews, the ratio of studies to positive and negative results is comparable. Empirical research is limited in expanding the analysis of the effects of the Internet. **Research on social networks, forums, video sharing, blogs is of less and worse quality with mixed results.

Заключение. Систематизированный обзор результатов отечественных, включая оригинальные, и зарубежных исследований с опорой на доказательные данные свидетельствует о том, что суицидальное поведение в подростковом возрасте - многофакторое явление, в основе формирования которого имеет сложное сочетанное воздействие как негативных внешних, так и индивидуальных личностных факторов, на фоне ослабления защитных факторов, систематизированный обзор результатов отечественных, включая оригинальные, и зарубежных исследований с опорой на доказательные данные свидетельствует о том, что суицидальное поведение в подростковом возрасте - многофакторое явление, в основе формирования которого имеет сложное сочетанное воздействие как негативных внешних, так и индивидуальных личностных факторов, на фоне ослабления защитных факторов. Между тем, отдельные суицидальной активности этой возрастной категории изучены недостаточно, что указывает на необходимость дальнейших исследований.
Литература / References:

1. Предотвращение самоубийств: глобальный императив. ВОЗ, 2014. 102 c. [Suicide prevention: a global imperative. WHO, 2014. 102 p.] (In Russ)

2. National suicide prevention strategies: progress, examples and indicators. WHO, 2018.

3. ВО3 Информационный бюллетень ко Всемирному дню психического здоровья 2018 г. Психическое здоровье подростков в Европейском регионе http://www.euro.who.int/_data/ assets/pdf_file/0006/383892/adolescent-mh-fs-rus.pdf?ua=1 [WHO regional office for Europe Newsletter for world mental health day 2018 mental health of adolescents in the European region http://www.euro.who.int/_data/assets/pdf_file/0006/383892/adolescentmh-fs-rus.pdf?ua=1] (In Russ)

4. Амбрумова А.Г., Тихоненко В.А. Диагностика суицидального поведения. Методические рекомендации. М, 1980. [Abramova A.G., Tikhonenko V.A. Diagnostics of suicidal behavior. Methodical recommendation. M, 1980.] (In Russ)

5. Nock M.K., Green J.G., Hwang I., et al. Prevalence, correlates, and treatment of lifetime suicidal behavior among adolescents: Results from the National Comorbidity Survey Replication Adolescent Supplement. JAMA Psychiatry. 2013; 70 (3): 300-310.

6. Личко А.Е. Суицидальное поведение. Психопатии и Л.: M, 1983. [Lichko A.E. Suicidal behavior. Psychopathy and accentuation of character in adolescents. Ed. $2^{\text {nd }}$ additional and pererab. L.: M, 1983.] (In Russ) акцентуации характера у подростков. Изд. 2-е доп. и перераб.
The complex nature of social networks, NSSH and SB requires an integrated approach. The potential of the Internet as an environment for anti-crisis events is ambiguous, but on the whole, participants of different ages rated it positively.

Conclusion: a systematic review of the results of domestic, including original, and foreign studies based on evidence suggests that suicidal behavior in adolescence is a multifactorial phenomenon, the formation of which has a complex combined effect of both negative external and individual personality factors on the grounds of weakening of protective factors. The need for further research is indicated. suicide in the general population. Psychiatr Serv. 2001; 52: 368-75.

8. Kokkevi A., Rotsika V., Arapaki A., Richardson C. Adolescents' self-reported suicide attempts, self-harm thoughts and their correlates across 17 European countries. J Child Psychol Psychiatry. 2012; 53 (4): 381-389.

9. Bridge J.A, Goldstein T.R., Brent DA. Adolescent suicide and suicidal behavior. J Child Psychol Psychiatry. 2006; 47: 372-394.

10. Page A., Lewis G., Kidger J., et al. Parental socio-economic position during childhood as a determinant of self-harm in adolescence. Soc Psychiatry Psychiatr Epidemiol. 2014; 49 (2): 193203. doi: 10.1007/s00127-013-0722-y

11. Czyz E.K., Berona J., King C.A. A prospective examination of the interpersonal-psychological theory of suicidal behavior among psychiatric adolescent inpatients. Suicide and Life-Threat Behav. 2015; 45 (2): 243-259.

12. Glenn C.R., Lanzillo E.C., Esposito E.C., et al. Examining the course of suicidal and nonsuicidal self-injurious thoughts and behaviors in outpatient and inpatient adolescents. J Abnorm Child Psychology. 2017; 45 (5): 971-983.

13. Reinherz H.Z., Tanner J.L., Berger S.R., et al. Adolescent suicidal ideation as predictive of psychopathology, suicidal behavior, and compromised functioning at age 30. Am J Psychiatry. 2006; 163 (7): 1226-1232.

14. McKinnon B., Gariépy G., Sentenaca M., Elgara F.J. Adolescent suicidal behaviours in 32 low- and middle-income countries. Bull World Health Organ. 2016; 94: 340-350. 
15. Kokkevi A., Rotsika V., Arapaki A., Richardson C. Adolescents' self-reported suicide attempts, self-harm thoughts and their correlates across 17 European countries. J Child Psychol Psychiatry. 2012; 53 (4): 381-389. doi: 10.1111/j.1469-7610.2011.02457.x

16. Hawton K., Saunders K.E., O’Connor R.C. Self-harm and suicide in adolescents. Lancet. 2012; 379: 2373-8232.

17. Brunner R., Kaess M., Parzer P., et al. Life-time prevalence and psychosocial correlates of adolescent direct self-injurious behavior: A comparative study of findings in 11 European countries. $J$ Child Psychol Psychiatry. 2014; 55: 337-348.

18. Cipriano A., Cella S., Cotrufo P .Nonsuicidal Self-injury: A Systematic Review. Front Psychol. 2017; 8: 1946.

19. Польская Н.А., Власова Н.В. Аутодеструктивное поведение в подростковом и юношеском возрасте. Консультативная и клиническая психология. 2015; 4: 176-190. [Polskaya N.A., Vlasova N.V. auto-Destructive behavior in adolescence and youth. Consulting and clinical psychology. 2015; 4: 176-190.] (In Russ)

20. Swannell S.V., Martin G.E., Page A., et al. Prevalence of nonsuicidal self-injury in nonclinical samples: systematic review, meta-analysis and meta-regression. Suicide Life Threat Behav. 2014; 44: 273-303.

21. Банников Г.С., Федунина Н.Ю., Павлова Т.С. и соавт. Ведущие механизмы самоповреждающего поведения у подростков: по материалам мониторинга в образовательных организациях. Консультативная психология и психотерапия. 2016; 24 (3): 42-68. [Bannikov G.S., Fedunina N.Yu., Pavlova T.S. et al. Leading mechanisms of self-harming behavior in adolescents: based on monitoring materials in educational organizations. Counseling psychology and psychotherapy. 2016; 24 (3): 42-68.] (In Russ)

22. Амбрумова А.Г. О некоторых особенностях суицидального поведения у детей и подростков. Журн. невропат. психиатрии им. С.С. Корсакова. 1983; 83 (10): 1544-1547. [Abramova A.G. About some features of suicidal behavior in children and adolescents. J. neuropath. psychiatry. S. S. Korsakov. 1983; 83 (10): 1544-1547.] (In Russ)

23. Kõlves K., de Leo D. Suicide methods in children and adolescents. Eur Child Adolesc Psychiatry. 2017; 26 (2): 155-164. doi: 10.1007/s00787-016-0865-y

24. https://www.who.int/mental_health/prevention/suicide/suicidepre vent/en/

25. Саркиапоне М., Положий Б.С. Суициды у детей и подростков. Российский психиатрический журнал. 2014; 3: 52-56. [Sarkiapone M., Polozhij B.S. Suicidy u detej i podrostkov / Suicides in children and adolescents / Rossijskij psihiatricheskij zhurnal. 2014; 3: 52-56.] (In Russ)

26. Суициды в России и Европе / Под ред. Б.С. Положего. М.: МИА, 2016. 212 с: ил. [Suicidy v Rossii i Evrope / Suicides in Russia and Europe / Pod red. B.S. Polozhego. M.: MIA, 2016. 212 s: il.] (In Russ)

27. Положий Б.С., Панченко Е.А. Суициды у детей и подростков в России: современная ситуация и пути ее нормализации / Электронный ресурс. Медицинская психология в России: электрон. науч. журн. 2012; 2. URL: http:// medpsy.ru. [Polozhiy B. S., Panchenko E. A. Suicides in children and adolescents in Russia: the current situation and ways to normalize it. $\backslash$ Electronic resource. Medical psychology in Russia: electron. science. Journ. 2012; 2. URL: http:// medpsy.ru] (In Russ)

28. Положий Б.С. Клиническая суицидология: этнокультуральные подходы. М.: ГНЦ ССП им. В.П. Сербского, 2006. 207 с. [Polozhiy B. S. Clinical suicidology: ethnocultural approaches. Moscow: SSC SSP im. V. P. Serbsky, 2006. 207 c.l (In Russ)

29. Макашева В.А., Слободская Е.Р. Суицидальное поведение несовершеннолетних: распространенность и факторы риска. Российский психиатрический журнал. 2014; 3; 33-40. [Makasheva V. A., Slobodskaya E. R. suicidal behavior of minors: prevalence and risk factors. Russian psychiatric journal. 2014; 3; 33-40.] (In Russ)

30. Морев М.В., Шматова Ю.Е., Любов Е.Б. Динамика суицидальной смертности населения России: региональный аспект. Суицицология. 2014; 5 (1); 3-11. [Morev M.V., Shmatova J.E., Lyubov E.B. Dynamics of suicide mortality in Russia: the Regional level. Suicidology. 2014; 5 (1); 3-11]. (In Russ)

31. Любов Е.Б. Клинико-социальное бремя близких жертвы суицида: Если бы... Суицидология. 2017; 8 (4): 56-76. [Lyubov E.B. Clinical and social burden for suicide survivors: if $i$ had dealt with it properly. Suicidology. 2017; 8 (4): 56-76.]. (In Russ)

32. Cha Ch.B., Franz P.J., Guzmán E.M., et al. Suicide among Youth: Epidemiology (Potential) Etiology, and Treatment. J Child Psychol Psychiatry. 2018; 59 (4): 460-482.

33. Giraud P., Fortanier C., Fabre G., et al. Suicide attempts by young adolescents: epidemiological characteristics of 517 15year-old or younger adolescents admitted in French emergency departments. Arch Pediatr. 2013; 20 (6): 608-615. doi: 10.1016/j.arcped.2013.03.024

34. Kalmár S. The possibilities of suicide prevention in adolescents. A holistic approach to protective and risk factors. Neuropsychopharmacol Hung. 2013; 15 (1): 27-39.

35. Lopez-Castroman J', Blasco-Fontecilla H', Courtet P, et al. Are we studying the right populations to understand suicide? World Psychiatry. 2015; 14 (3): 368-369. doi: 10.1002/wps.20261

36. Уманский М.С., Зотова Е.П. Суицидальные попытки: соотношение мужчин и женщин. Девиантология. 2018; 2 (1): 30-35. [Umansky M.S., Zotova E.P. Suicide attempts: the ratio of men and women. Deviant Behavior (Russia). 2018; 2 (1): 30-35.] (In Russ)

37. Glenn C.R., Cha C.B., Kleiman E.M., Nock M.K. Understanding suicide risk within the Research Domain Criteria (RDoC) framework: Insights, challenges, and future research considerations. Clin Psychol Sci. 2017; 5 (3): 568-592.

38. Любов Е.Б., Сумароков Ю.М., Конопленко Э.Р Жизнестойкость и факторы риска суицидального поведения коренных малочисленных народов Севера России. Суииидология. 2015; 6 (3): 23-30. [Lyubov E.B., Sumarokov Y.A., Konoplenko E.R. Resilience and suicide behaviour risk factors in indigenous peoples of the Russian North. Suicidology. 2015; 6 (3): 23-30.] (In Russ)

39. Castellanos D., Kosoy J.E., Ayllon K.D., Acuna J. Presence of alcohol and drugs in hispanic versus non-hispanic youth suicide victims in Miami-Dade County, Florida. J Immigr Minor Health. 2016; 18 (5): 1024-1031. doi: 10.1007/s10903-016-0418-y

40. David-Ferdon C., Crosby A.E., Caine E.D., et al. CDC Grand Rounds: Preventing Suicide Through a Comprehensive Public Health Approach. MMWR Morb Mortal Wkly Rep. 2016; 65 (34): 894-897. doi: 10.15585/mmwr.mm6534a2

41. Lindsey M.A., Brown D.R., Cunningham M. Boys do(n't) cry: Addressing the unmet mental health needs of African American boys. Am J Orthopsychiatry. 2017; 87 (4): 377-383. doi: 10.1037/ort0000198

42. Scott L.N., Pilkonis P.A., Hipwell A.E., et al. Non-suicidal selfinjury and suicidal ideation as predictors of suicide attempts in adolescent girls: a multi-wave prospective study. Compr Psychiatry. 2015; 58: 1-10

43. Owens D., Horrocks J., House A. Fatal and non-fatal repetition of self-harm: Systematic review. Br J Psychiatry. 2002; 181: 193-199.

44. Kingsbury S.J. Clinical components of suicidal intent in adolescent overdose. J Am Acad Child Adolesc Psychiatry. 1993; 32 (3): $518-520$.

45. King R.A., Schwab-Stone M., Flisher A.J., Greenwald S., Kramer R.A., Goodman S.H., Lahey B.B., Shaffer D., Gould M.S. Psychosocial and risk behavior correlates of youth suicide attempts and suicidal ideation. J Am Acad Child Adolesc Psychiatry. 2001; 40 (7): 837-846.

46. Borowsky I.W., Ireland M., Resnick M.D. Adolescent suicide attempts: Risks and protectors. Pediatrics. 2001; 107: 485-493.

47. Ristić-Dimitrijević R., Lazić D., Nenadović M., Djokić-Pjescić K., Klidonas N., Stefanović V. Aggression in adolescents: characteristics and treatment. Srp Arh Celok Lek. 2011; 139 Suppl 1: 61-64.

48. Kasen S., Cohen P., Chen H. Developmental course of impulsivity and capability from age 10 to age 25 as related to trajectory of suicide attempt in a community cohort. Suicide Life Threat Behav. 2011; 41 (2): 180-192. doi: 10.1111/j.1943-278X.2011.00017.x

49. Brent D.A., Baugher M., Bridge J., et al. Age - And sex-related risk factors for adolescent suicide. J Am Acad Child Adolesc Psychiatry. 1999; 38: 1497-1505.

50. Yen S., Shea M.T., Sanislow C.A., et al. Personality traits as prospective predictors of suicide attempts. Acta Psychiatr Scand. 2009; 120 (3): 222-229. doi: 10.1111/j.1600-0447.2009.01366.x

51. Kaplow J.B., Gipson P.Y., Horwitz A.G., Burch B.N., King C.A. Emotional suppression mediates the relation between adverse life events and adolescent suicide: implications for prevention. Prev Sci. 2014; 15 (2): 177-185. doi: 10.1007/s11121-013-0367-9

52. Smith M.M., Sherry S.B., Chen S., et al. The perniciousness of perfectionism: A meta-analytic review of the perfectionismsuicide relationship. J Pers. 2018; 86 (3): 522-542. doi: 10.1111/jopy. 12333

53. Roxborough H.M., Hewitt P.L., Kaldas J., et al. Perfectionistic self-presentation, socially prescribed perfectionism, and suicide in youth: a test of the perfectionism social disconnection model. Suicide Life Threat Behav. 2012; 42 (2): 217-233. doi: 10.1111/j.1943-278X.2012.00084.X

54. Kattimani S., Sarkar S., Rajkumar R.P., Menon V. Stressful life events, hopelessness, and coping strategies among impulsive suicide attempters. J Neurosci Rural Pract. 2015; 6: 171-176. 
55. Mathew A., Nanoo S. Psychosocial stressors and patterns of coping in adolescent suicide attempters. Indian J Psychol Med. 2013; 35 (1): 39-46. doi: 10.4103/0253-7176.112200

56. Friedman M.S., Marshal M.P., Guadamuz T.E., et al. A metaanalysis of disparities in childhood sexual abuse, parental physical abuse, and peer victimization among sexual minority and sexual nonminority individuals. Am J Publ Health. 2011; 8: 1481-1494.

57. Raifman J., Moscoe E., Austin S.B., McConnell M. Differencein-differences analysis of the association between state same-sex marriage policies and adolescent suicide attempts. JAMA Pediatrics. 2017; 171 (4): 350-356.

58. Герасимова О.Ю., Семченко Л.Н., Никонов А.С. Психологические особенности суицидального поведения в подростковом возрасте. Девиантология. 2019; 3 (1): 30-36. [Gerasimova O.Yu., Semchenko L.N., Nikonov A.S. Psychological peculiarities of suicidal behavior in adolescent age. Deviant Behavior (Russia). 2019; 3 (1): 30-36.] (In Russ)

59. Franklin J.C., Ribeiro J.D., Fox K.R., et al. Risk factors for suicidal thoughts and behaviors: A meta-analysis of 50 years of research. Psychol Bull. 2017; 143 (2): 187-232.

60. Randall J.R., Walld R., Finlayson G., Sareen J., Martens P.J., Bolton J.M. Acute risk of suicide and suicide attempts associated with recent diagnosis of mental disorders: a population-based propensity score-matched analysis. Can J Psychiatry. 2014; 59 (10): 531-538.

61. Kitagawa Y., Shimodera S., Togo F. et al. Suicidal feelings interferes with help-seeking in bullied adolescents. PLOS ONE. 2014; 9 (9): el06031.

62. Pisani A.R., Wyman P.A., Petrova M., et al. Emotion regulation difficulties, youth-adult relationships, and suicide attempts among high school students in underserved communities. J Youth Adolesc. 2013; 42 (6): 807-820. doi: 10.1007/s10964-012-9884-2

63. Burke T.A., Connolly S.L., Hamilton J.L. et al. Cognitive risk and protective factors for suicidal ideation: A twoyear longitudinal study in adolescence. J Abnorm Child Psychology. 2016; 44: 1145-1160.

64. Kovacs M., George C.J. Maladaptive mood repair predicts suicidal behaviors among young adults with depression histories. $J$ Affect Disord. 2019; Nov 14. pii: S0165-0327(19)30683-4. doi: 10.1016/j.jad.2019.11.091

65. Weissman M.M., Wolk S., Goldstein R.B., et al. Depressed adolescents grown up. JAMA. 1999; 281 (18): 1707-1713.

66. McGee R., Williams S., Nada-Raja S. Low self-esteem and hopelessness in childhood and suicidal ideation in early adulthood. $J$ Abnorm Child Psychol. 2001; 29 (4): 281-291.

67. Hetrick S.E., Parker A.G., Robinson J., Hall N., Vance A. Predicting suicidal risk in a cohort of depressed children and adolescents. Crisis. 2012; 33 (1): 13-20.

68. Wolff J.C., Davis S., Liu R.T., et al. Trajectories of Suicidal Ideation among Adolescents Following Psychiatric Hospitalization. J Abnorm Child Psychol. 2018; 46 (2): 355-363. doi: 10.1007/s10802-017-0293-6

69. Esposito C., Spirito A., Boergers J., Donaldson D. Affective, behavioral, and cognitive functioning in adolescents with multiple suicide attempts. Suicide Life Threat Behav. 2003; 33 (4): 389-399.

70. Khurshid K.A. Comorbid insomnia and psychiatric disorders: An update. Innovat. Clin. Neurosci. 2018; 15: 28-32.

71. Pompili M., Mancinelli I., Girardi P., et al. Suicide in anorexia nervosa: a meta-analysis. Int J Eat Disord. 2004; 36 (1): 99-103.

72. Shlosberg D., Zalsman G., Shoval G. Emerging issues in the relationship between adolescent substance use and suicidal behavior. Isr J Psychiatry Relat Sci. 2014; 51 (4): 262-267.

73. Любов Е.Б., Цупрун В.Е. Суицид и шизофрения: факторы риска и эпидемиология. Психическое здоровье. 2013; 11 (90) 66-76. [Lyubov E. B., Tsuprun V. E. Suicide and schizophrenia: risk factors and epidemiology. Mental health. 2013; 11 (90): 6676.] (In Russ)

74. Chang B., Gitlin D., Patel R. The depressed patient and suicidal patient in the emergency department: evidence-based management and treatment strategies. Emerg Med Pract. 2011; 13 (9): 1-23.

75. Зотов П.Б., Любов Е.Б. Суицидальное поведение при соматических и неврологических болезнях. Тюменский медииинскии журнал. 2017; 19 (1): 3-24. [Zotov P.B., Lyubov E.B. Suicidal behavior in the medical patients. Tyumen Medical Journal. 2017; 19 (1): 3-24.] (In Russ)

76. Sommerfeldt S.L., Cullen K.R., Han G., et al. Executive attention impairment in adolescents with major depressive disorder. J Clin Child Adolesc Psychology. 2016; 45 (1): 69-83.

77. Arie M., Apter A., Orbach I., Yefet Y., Zalsman G. Autobiographical memory, interpersonal problem solving, and suicidal behavior in adolescent inpatients. Compr Psychiatry. 2008; 49 (1): 22-29.
78. Ефимова А.Д. Связь любовной аддикции с иными вариантами аддиктивного поведения и саморазрушающим поведением. Девиантология. 2018; 2 (2): 18-25. [Efimova A.D. Relationship of love addiction with other addictive behaviors and self-destructive behavior. Deviant Behavior (Russia). 2018; 2 (2): 18-25.] (In Russ)

79. Qualter P, Brown SL, Munn P, Rotenberg KJ. Childhood loneliness as a predictor of adolescent depressive symptoms: an 8-year longitudinal study. Eur Child Adolesc Psychiatry. 2010; 19 (6): 493-501.

80. Pestian J.P., Sorter M., Connolly B., et al. A machine learning approach to identifying the thought markers of suicidal subjects: a prospective multicenter trial. Suicide Life Threat Behav. 2017; 47 (1): 112-121. doi: 10.1111/sltb.12312

81. Freuchen A., Kjelsberg E., Lundervold A.J., Grøholt B. Differences between children and adolescents who commit suicide and their peers: A psychological autopsy of suicide victims compared to accident victims and a community sample. Child Adolesc Psychiatry Ment Health. 2012; 6: 1. doi: 10.1186/1753-2000-6-1

82. Zhang J., Ma Z. Patterns of life events preceding the suicide in rural young Chinese: a case control study. J Affect Disord. 2012; 140 (2): 161-167. doi: 10.1016/j.jad.2012.01.010

83. Arun P., Chavan B.S. Stress and suicidal ideas in adolescent students in Chandigarh. Indian J Med Sci. 2009; 63 (7): 281-287. doi: 10.4103/0019-5359.55112

84. Tang T.C., Jou S.H, Ko C.H., et al. Randomized study of schoolbased intensive interpersonal psychotherapy for depressed adolescents with suicidal risk and parasuicide behaviors. Psychiatry Clin. Neurosci. 2009; 63 (4): 463-470.

85. Qin P., Mortensen P.B., Pedersen C.B. Frequent change of residence and risk of attempted and completed suicide among children and adolescents. Arch Gen Psychiatry. 2009; 66 (6): 628632. doi: 10.1001/archgenpsychiatry.2009.20

86. Cash S.J., Bridge J.A. Epidemiology of youth suicide and suicidal behavior. Curr Opin Pediatr. 2009; 21 (5): 613-619. doi: 10.1097/MOP.0b013e32833063e1

87. Johnson J.G., Cohen P., Gould M.S., Kasen S., Brown J., Brook J.S. Childhood adversities, interpersonal difficulties, and risk for suicide attempts during late adolescence and early adulthood. Arch Gen Psychiatry. 2002; 59 (8): 741-749.

88. Donath C., Graessel E., Baier D., Bleich S., Hillemacher T. Is parenting style a predictor of suicide attempts in a representative sample of adolescents? BMC Pediatr. 2014; 14.

89. Brent D.A., Mann J.J. Family genetic studies, suicide, and suicidal behavior. Am J Med Genet C Semin Med Genet. 2005; 133 (1): $13-24$

90. Fergusson D.M., Boden J.M., Horwood L.J. Exposure to childhood sexual and physical abuse and adjustment in early adulthood. Child Abuse Neglect. 2008; 32 (6): 607-619.

91. Розанов В.А. Стресс-индуцированные эпигенетические феномены - еще один вероятный биологический фактор суицида. Суицидология. 2015; 6 (3): 3-19. [Rozanov V.A. Stressinduced epigenetic phenomena - one more biological mechanism of suicide. Suicidology. 2015; 6 (3): 3-19.] (In Russ)

92. Prigerson H.G., Bridge J., Maciejewski P.K., Beery L.C., et al. Influence of traumatic grief on suicidal ideation among young adults. Am J Psychiatry. 1999; 156 (12): 1994-1995.

93. Sandin B., Chorot P., Santed M.A., et al. Negative life events and adolescent suicidal behavior: a critical analysis from the stress process perspective. J Adolesc. 1998; 21 (4): 415-426.

94. Holland K.M., Vivolo-Kantor A.M., Logan J.E., Leemis R.W. Antecedents of Suicide among Youth Aged 11-15: A Multistate Mixed Methods Analysis. J Youth Adolesc. 2017; 46 (7): 1598 1610 .

95. Castellví P., Miranda-Mendizábal A., Parés-Badell O., et al. Exposure to violence, a risk for suicide in youths and young adults. A meta-analysis of longitudinal studies. Acta Psychiatr Scand. 2017; 135 (3): 195-211.

96. Dufort M., Stenbacka M., Gumpert C.H. Physical domestic violence exposure is highly associated with suicidal attempts in both women and men. Results from the national public health survey in Sweden. Eur J Public Health. 2015; 25 (3): 413-418. doi: 10.1093/eurpub/cku198

97. Brown J., Cohen P., Johnson J.G., Smailes E.M. Childhood abuse and neglect: specificity of effects on adolescent and young adult depression and suicidality. J Am Acad Child Adolesc Psychiatry. 1999; 38 (12): 1490-1496.

98. Ystgaard M., Hestetun I., Loeb M., Mehlum L. Is there a specific relationship between childhood sexual and physical abuse and repeated suicidal behavior? Child Abuse Negl. 2004; 28 (8): 863-875.

99. Wagner B.M. Family risk factors for child and adolescent suicidal behavior. Psychol Bull. 1997; 121 (2): 246-298.

100. Dunn E.C., McLaughlin K.A., Slopen N., et al. Developmental timing of child maltreatment and symptoms of depression and 
suicidal ideation in young adulthood: Results from the National Longitudinal Study of Adolescent Health. Depression and Anxiety. 2013; 30 (10): 955-964.

101. Gomez S.H., Tse J., Wang Y., et al. Are there sensitive periods when child maltreatment substantially elevates suicide risk? Results from a nationally representative sample of adolescents. Depression Anxiety. 2017; 34: 734-741.

102. Martin G., Bergen H.A., Richardson A.S., et al. Sexual abuse and suicidality: gender differences in a large community sample of adolescents. Child Abuse Negl. 2004; 28 (5): 491-503.

103. Miller A.B., Jenness J.L., Oppenheimer C.W., et al. Childhood emotional maltreatment as a robust predictor of suicidal ideation: A 3-year multi-wave, prospective investigation. J Abnorm Child Psychology. 2016; 45 (1): 105-116.

104. Thompson R., Proctor L.J., English D.J., et al. Suicidal ideation in adolescence: examining the role of recent adverse experiences. J Adolesc. 2012; 35 (1): 175-186.

105. Norman R.E., Byambaa M., De R., et al. The long-term health consequences of child physical abuse, emotional abuse, and neglect: a systematic review and meta-analysis. PLoSmed. 2012; 9 (11): e1001349

106. Molnar B.E., Berkman L.F., Buka S.L. Psychopathology, childhood sexual abuse and other childhood adversities: relative links to subsequent suicidal behaviour in the US. Psychol Med. 2001; 31 (6): 965-977.

107. Khan A., McCormack H.C., Bolger E.A., et al. Childhood maltreatment, depression, and suicidal ideation: critical importance of parental and peer emotional abuse during developmental sensitive periods in males and females. Front Psychiatry. 2015; 6.
108. Geoffroy M.C., Boivin M., Arseneault L., et al. Associations between peer victimization and suicidal ideation and suicide attempt during adolescence: Results from a prospective population-based birth cohort. J Am Acad Child Adolesc Psychiatry. 2016; 55 (2): 99-105.

109. Vergara G.A., Stewart J.G., Cosby E.A., et al. Non-Suicidal selfinjury and suicide in depressed Adolescents: Impact of peer victimization and bullying. J Affect Dis. 2019; 245: 744-749.

110. Любов Е.Б. Роль СМИ в профилактике суицидального поведения Национальное руководство по суицидологии Под ред. Б.С. Положего. Москва: МИА, 2019. С. 512-34. [Lyubov E. B. The role of the media in the prevention of suicidal behavior / National guide to suicidology / ed. Moscow: MIA, 2019. Pp. 512-34.] (In Russ)

111. Haw C., Hawton K., Niedzwiedz C., Platt S. Suicide clusters: a review of risk factors and mechanisms. Suicide Life Threat Behav. 2013; 43 (1): 97-108.

112. Niederkrotenthaler T., Fu K.W., Yip P.S., et al. Changes in suicide rates following media reports on celebrity suicide: a meta-analysis. J Epidemiol Community Health. 2012; 66 (11): 1037-1042.

113. Ho R.C., Zhang M.W., Tsang T.Y., et al. The association between Internet addiction and psychiatric co-morbidity: A metaanalysis. BMC Psychiatry. 2014; 14 (1): 183.

114. Mars B., Heron J., Biddle L., et al. Exposure to, and searching for, information about suicide and self-harm on the Internet: Prevalence and predictors in a population based cohort of young adults. J Affect Disord. 2015; 185: 239-245.

115. John A., Glendenning A.C., Marchant A., et al. Self - harm, suicidal behaviours, and cyberbullying in children and young people: systematic review. J Med Internet Res. 2018; 20 (4): e129.

\section{SELF-HARMING BEHAVIOR OF ADOLESCENTS: DEFINITIONS, EPIDEMIOLOGY, RISK FACTORS AND PROTECTIVE FACTORS. The Message I}
E.B. Lyubov'
P.B. Zotov'
G.S. Bannikov ${ }^{1,3}$
${ }^{1}$ Moscow Institute of Psychiatry - branch of National medical research centre of psychiatry and narcology by name V.P.Serbsky, Moskow, Russia; lyubov.evgeny@mail.ru
2Tyumen State Medical University, Tyumen, Russia; note72@yandex.ru
${ }^{3}$ Moscow State University of Psychology and Education, Moscow, Russia; bannikov68@mail.ru

In a series of reviews, the results of national, including original, and foreign studies based on evidence of suicidal behavior are systematized and critically interpreted. This Message I gives clear characteristics of individual forms of suicidal behavior and non-suicidal self-harm, their differences, epidemiological indicators in adolescence and in comparison with the adult population. Risk factors and antisuicidal protection, methods of suicidal actions are examined in detail. The role of such indicators as sex, age, race and ethnicity, etc. in the suicidal activity of people of this age category is discussed. When assessing suicidal risk, the important role of suicide history (attempted suicide in the past) and the presence of non-suicidal self-harm, risky behavior are shown. The data on affective, cognitive and social risk factors for suicidal behavior, personality and psychological characteristics are given. In particular, the authors discuss the role of aggression and impulsivity, neurotism, negative affectivity, low self-esteem, insufficient stress resistance, sexual orientation, the use of surfactants, etc. In conclusion, the authors surmise that the development of suicidal behavior in adolescence is multifactorial and needs further research.

Keywords: autoaggression, suicide, suicide attempt, adolescents, suicidogenesis models, risk factors, prevention

Вкмад авторов:

Е.Б. Аюбов: разработка дизайна исследования, обзор публикаций, написание и редактирование текста рукописи; П.Б. Зотов: обзор публикаций по теме статьи, написание и редактирование текста рукописи;

Г.С. Банников: обзор публикаций по теме статьи.

Authors' contributions:

E.B. Lyubov: developing the research design, reviewing of publications, article writing, article editing;

P.B. Zotov: $\quad$ reviewing of publications of the article's theme; article writing, article editing;

G.S. Bannikov: reviewing of publications of the article's theme.

Финансирование: Данное исследование не имело финансовой поддержки.

Financing: The study was performed without external funding.

Конфмикт интересов: Авторы заявцяют об отсутствии конфмикта интересов.

Conflict of interest: The authors declare no conflict of interest.

Статья поступима / Article received: 02.08.2019. Принята к публикации / Accepted for publication: 19.12.2019.

Для цитирования: Любов Е.Б., Зотов П.Б., Банников Г.С. Самоповреждающее поведение подростков: дефиниции, эпидемиология, факторы риска и защитные факторы. Сообщение I. Суицидология. 2019; 10 (4): 16-46. doi.org/10.32878/suiciderus.19-10-04(37)-16-46

For citation: $\quad$ Lyubov E.B., Zotov P.B., Bannikov G.S. Self-harming behavior of adolescents: definitions, epidemiology, risk factors and protective factors. The Message I. Suicidology. 2019; 10 (4): 16-46. (In Russ) doi.org/10.32878/suiciderus.19-10-04(37)-16-46 